\title{
Post-Translational Modifications of Retroviral HIV-1 Gag Precursors: An Overview of Their Biological Role
}

\author{
Charlotte Bussienne (D), Roland Marquet ${ }^{(D)}$, Jean-Christophe Paillart $(\mathbb{D}$ and Serena Bernacchi *(D) \\ Architecture et Réactivité de l'ARN, UPR 9002, IBMC, CNRS, Université de Strasbourg, 2 allée Konrad Roentgen, \\ CEDEX F-67084 Strasbourg, France; c.bussienne@ibmc-cnrs.unistra.fr (C.B.); \\ r.marquet@ibmc-cnrs.unistra.fr (R.M.); jc.paillart@ibmc-cnrs.unistra.fr (J.-C.P.) \\ * Correspondence: s.bernacchi@ibmc-cnrs.unistra.fr; Tel.: +33-(0)3-8841-7040
}

check for updates

Citation: Bussienne, C.; Marquet, R.; Paillart, J.-C.; Bernacchi, S.

Post-Translational Modifications of Retroviral HIV-1 Gag Precursors: An Overview of Their Biological Role. Int. J. Mol. Sci. 2021, 22, 2871.

https://doi.org/10.3390/ijms22062871

Academic Editor: Kwang-Hyun Baek

Received: 25 January 2021

Accepted: 9 March 2021

Published: 11 March 2021

Publisher's Note: MDPI stays neutral with regard to jurisdictional claims in published maps and institutional affiliations.

Copyright: (c) 2021 by the authors. Licensee MDPI, Basel, Switzerland. This article is an open access article distributed under the terms and conditions of the Creative Commons Attribution (CC BY) license (https:/ / creativecommons.org/licenses/by/ $4.0 /)$.

\begin{abstract}
Protein post-translational modifications (PTMs) play key roles in eukaryotes since they finely regulate numerous mechanisms used to diversify the protein functions and to modulate their signaling networks. Besides, these chemical modifications also take part in the viral hijacking of the host, and also contribute to the cellular response to viral infections. All domains of the human immunodeficiency virus type 1 (HIV-1) Gag precursor of 55-kDa (Pr55 Gag), which is the central actor for viral RNA specific recruitment and genome packaging, are post-translationally modified. In this review, we summarize the current knowledge about HIV-1 Pr55Gag PTMs such as myristoylation, phosphorylation, ubiquitination, sumoylation, methylation, and ISGylation in order to figure out how these modifications affect the precursor functions and viral replication. Indeed, in HIV-1, PTMs regulate the precursor trafficking between cell compartments and its anchoring at the plasma membrane, where viral assembly occurs. Interestingly, PTMs also allow Pr55Gag to hijack the cell machinery to achieve viral budding as they drive recognition between viral proteins or cellular components such as the ESCRT machinery. Finally, we will describe and compare PTMs of several other retroviral Gag proteins to give a global overview of their role in the retroviral life cycle.
\end{abstract}

Keywords: HIV-1; Pr55 ${ }^{\mathrm{Gag}}$ precursor; post-translational modifications; retroviral Gag precursors; retroviral life cycle

\section{Introduction}

Post translational modifications (PTMs) introduce a vast diversity in proteome including addition of chemical groups, like phosphorylation, methylation, acetylation, redoxbased modifications, or alternatively, addition of polypeptides like ubiquitination, sumoylation or ISGylation. PTMs thus play a key role in functional proteomic by regulating proteins activity, their localization, and the interaction with cellular or viral factors. Even though many proteins are modified shortly after translation, PTMs can also occur at different steps such as after protein folding or protein re-localization to influence their biological activity at those specific sites (for reviews see [1,2]). Besides, depending on the nature of the modification, they can also finely tune reversible processes. Consequently, analysis of PTMs can provide an invaluable insight into cellular functions.

Viruses rely on the protein synthesis machinery of the host to support the production of viral progeny, and several cellular pathways are modulated by viruses to achieve the critical steps in viral replication. Hence, it is not surprising that viruses developed different strategies to either counteract or exploit PTMs of cellular factors, and that many viral proteins carry PTMs. Interestingly, PTMs are strongly involved in the regulation of different steps of the retrovirus viral cycle (for reviews see [3,4]). More specifically, in the HIV-1 (human immunodeficiency virus type 1) context, PTMs within the 55-kDa viral precursor, Pr55 Gag (or Gag), were found to be necessary for regulating the last phase of the viral cycle, leading to the assembly of viral particles. Besides, several pieces of evidence have shown that other retroviral Gag carry various PTMs regulate viral replication and 
pathogenesis. This review will summarize our current knowledge on PTMs observed in HIV-1 Pr55 ${ }^{\mathrm{Gag}}$ and in other retroviral Gag proteins. Considering the role of the PMTs in the retroviral life cycle, the analysis of PTMs in retroviral Gag precursors could be particularly important for a deeper understanding of the molecular mechanisms driving retroviral replication. In a further step, this knowledge could contribute to the identification of new targets, and the design of new treatments against retroviral replication.

\section{HIV-1 Pr55Gag}

The HIV-1 Pr55 ${ }^{\text {Gag }}$ precursor (Figure 1a) plays a crucial for genomic RNA (gRNA) packaging, since it specifically selects the full-length gRNA amongst many other RNAs (cellular and spliced viral RNAs) and this process involves specific interactions between Pr55 Gag and the highly structured $5^{\prime}$ region of the gRNA [5,6], which contains the packaging signal (Psi) spanning SL (stem-loop) 1 to SL4 in the $5^{\prime}$-end region of gRNA [7-9] (Figure 1b). In cells, the HIV-1 gRNA dimer in association with low-order Pr55 ${ }^{\mathrm{Gag}}$ multimers [10-12] forms a viral ribonucleoprotein complex that traffics to the plasma membrane (PM) where the assembly of the viral particle occurs (for reviews see [13-15]). HIV-1 Pr55 ${ }^{\mathrm{Gag}}$ is composed of four structural domains named matrix (MA), capsid (CA), nucleocapsid (NC), p6, and two spacer peptides (p2 and p1) (Figure 1a) [16] and each of them carry PTMs.

From the $\mathrm{N}$-terminus, the $17 \mathrm{kDa}$ MA domain that possesses a bipartite signal leads to Pr55 Gag interaction with the PM. The first signal corresponds to the N-terminal myristoylated Glycine 2 (G2) (see § "HIV-1 Pr55Gag Myristoylation"), while the second one is constituted by a highly basic region (HBR) at the MA surface (for a review see [17]). MA was also found to interact with nucleic acids such as host tRNAs [18], and recent findings showed that MA-RNA binding ensures the specific interaction between Pr55 Gag and the PM, by preventing nonspecific binding of Gag to intracellular membranes $[19,20]$. The CA is a $24 \mathrm{kDa}$ domain that drives Pr55 ${ }^{\mathrm{Gag}}$ multimerization and leads to formation of the viral core [21-23]. Next, NC is a $7 \mathrm{kDa}$ domain, which is crucial for specific interaction with gRNA and for the incorporation of tRNA ${ }^{\text {Lys3 } 3}$, which is the primer for reverse transcription. NC displays two zinc finger motifs $(\mathrm{CCHC})$ that specifically interact with the Psi (Figure 1b) $[24,25]$. This domain also contributes to Pr55 ${ }^{\mathrm{Gag}}$ multimerization thus promoting viral assembly [26-28]. At the C-terminal end of Pr55 Gag, the unstructured p6 domain of $6 \mathrm{kDa}$ is required for specific binding to the gRNA [29], and is involved in the recruitment of the ESCRT (Endosomal Sorting Complex Required for Transport) machinery that regulate viral particle budding. Finally, Pr55 ${ }^{\mathrm{Gag}}$ codes for two spacer peptides, sp1 and sp2 (also named p2 and p1, respectively), regulating the kinetics of Pr55Gag maturation.

(a)

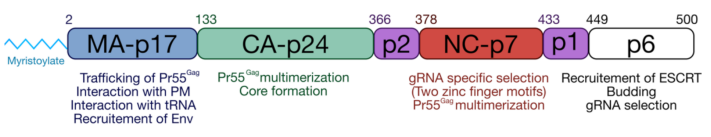

(b)

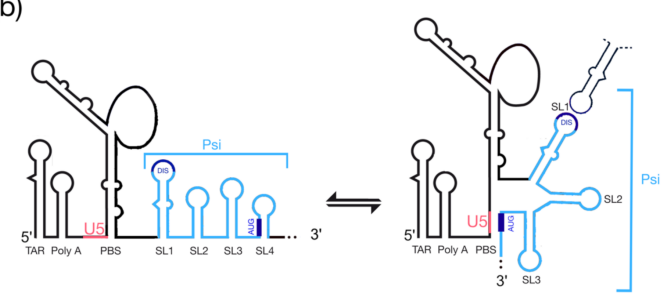

Figure 1. Pr55 ${ }^{\text {Gag }}$ and the $5^{\prime}$ UTR of HIV-1 genomic RNA. (a) Functional domains of Pr55 $5^{\text {Gag }}$ and a short description of their roles. (b) Schematic representation of the secondary structure model of the $5^{\prime} \mathrm{UTR}$ (adapted from [29]). TAR: transactivation response element; Poly-A: 5'-copy of the polyadenylation signal; PBS: Primer Biding Site; DIS: Dimerization Initiation Site; Psi: packaging signal spanning SL1 to SL4; U5: unique region at the $5^{\prime}$ end. The structure represents the U5-AUG conformation $[5,6]$. 
The next sections of this revue will describe which PMTs are carried by the different Pr55 Gag domains and what are their roles in the viral life cycle.

\section{HIV-1 Pr55 Gag Myristoylation}

The myristoylation is a co-translational and irreversible modification consisting in the addition of a 14-carbon saturated fatty acid myristate to the protein via an amid bond by the N-myristoyl-transferase (NMT) (for reviews see [30-32]). The myristoylation can be achieved on an internal glycine $(G)$ inside a consensus sequence recognized by NMTs, which is G-X2-X3-X4-(S/T/C)-X6 (Figure 2a). The G residue at the first position is necessary for this PMT, while at the second position there is preferentially an uncharged residue (except for proline $(\mathrm{P})$ ) or an aromatic amino acid. At the fifth position, uncharged residues are found, preferentially serine (S) and threonine (T) (for a review see [33]), while $\mathrm{P}$ is not accepted at the sixth position [34]. In sum, three regions finely regulate myristoylation: the binding pocket (positions from 1 to 6 ), the catalytic domain (positions from 7 to 10) and the hydrophilic linker (position from 11 to 17) [34,35] (Figure 2a).

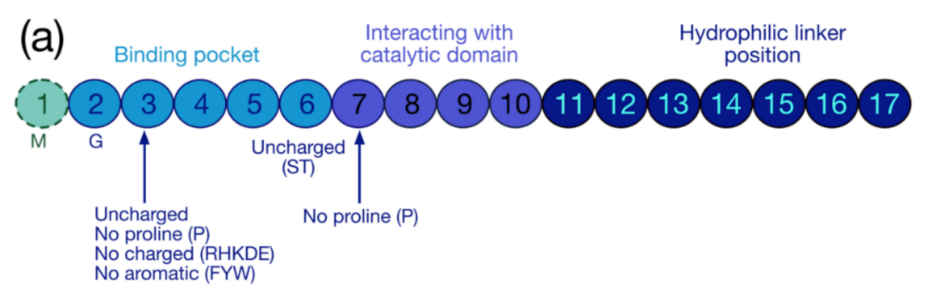

(b)

\begin{tabular}{|c|c|c|c|}
\hline & Family & Virus & Sequence \\
\hline & Lentivirus & $\begin{array}{l}\text { HIV-1 } \\
\text { HIV-2 }\end{array}$ & $\begin{array}{l}\text { MGARASVLSG GELDKWE } \\
\text { MGARGSVLSG KKTDELE }\end{array}$ \\
\hline Myristoyation & $\begin{array}{l}\text { Betaretrovirus } \\
\text { Betaretrovirus } \\
\text { Gammaretrovirus } \\
\text { Deltaretrovirus }\end{array}$ & $\begin{array}{l}\text { MMTV } \\
\text { MPMV } \\
\text { HERK } \\
\text { MoMuLV } \\
\text { HTLV-1 } \\
\text { BLV }\end{array}$ & $\begin{array}{ll}\text { MGQKLFVSVL } & \text { QRLLSER } \\
\text { MGQELSQHER } & \text { YVEQLKQ } \\
\text { MGQTKSKIKS } & \text { KYASYLS } \\
\text { MGQTVTTPLS } & \text { LTLGHWK } \\
\text { MGQIFSRSAS } & \text { PIPRPPR } \\
\text { MGNSPSYNPP } & \text { AGISPSD }\end{array}$ \\
\hline $\begin{array}{c}\text { No } \\
\text { Myristoylation }\end{array}$ & $\begin{array}{l}\text { Alpharetrovirus } \\
\text { Lentivirus } \\
\text { Spumavirus }\end{array}$ & $\begin{array}{l}\text { RSV } \\
\text { EIAV } \\
\text { FV }\end{array}$ & $\begin{array}{ll}\text { MEAVIKVISS } & \text { ACKTYCG } \\
\text { MGDPLTWSKA } & \text { LKKLEKV } \\
\text { MASGSNVEEY } & \text { ELDVEAL }\end{array}$ \\
\hline
\end{tabular}

Figure 2. Protein sequence required for myristoylation and sequences of retroviral myristoylated MA domains. (a) Pro-myristoylated consensus sequence underlying the three regions regulating myristoylation: the binding pocket (positions 1-6), the catalytic domain (positions 7-10) and the hydrophilic linker (positions 11-17) [34,35]. (b) Comparison of the first 17 residues of myristoylated MA domains in different retroviruses. Myristoylation is generally conserved in retroviruses such as lentivirus (HIV-1), betaretrovirus (Mason-Pfizer monkey virus (MPMV), mouse mammary tumor virus (MMTV), and human endogenous retrovirus type K (HERK)), gammaretrovirus (Moloney murine leukemia virus (MoMuLV) and murine leukemia virus (MLV)), and deltaretrovirus (human T-lymphotropic viruses (HTLV-1) and bovine leukemia virus (BLV)), but not in alpharetrovirus (Rous sarcoma virus (RSV)), some other lentivirus (equine infectious anemia virus (EIAV)), and in spumavirus (foamy virus (FV)).

Myristoylation is rather conserved in retroviruses (Figure 2b) (For reviews see [17,36] and $[37,38])$, and this PTM globally regulates the interaction of retroviral precursors with membranes and sub-membrane domains, such as lipid rafts. However, this modification is not sufficient by itself for membrane binding, and a distant polybasic domain is thus required to complete the optimal attachment of myristoylated proteins to the PM (for reviews see [39,40]). In HIV-1, this task is reached by the HBR spanning residues 17 to 31 of the MA domain, which contributes to a strengthening of the interaction with the PM thanks to electrostatic interactions with the negatively charged PI(4,5)P2 [41-43]. 
The myristoyl moiety can be exposed or sequestered in the hydrophobic pocket of the mature MA (Figure 3a,b) by the so-called myristoyl-conformational switch [37,39,42,44,45], which controls the exposure of myristoyl group for insertion into the PM, thus contributing to the prevention of aberrant interactions with intracellular membranes. The myristate exposure was found to be triggered by the interactions occurring between Pr55 Gag and PI(4,5)P2 [41]. Besides, NMR studies demonstrated that myristate exposure is also regulated by the trimerization of the protein [37,42], and this would explain why the mature MA displays a lower affinity for membranes in comparison with the full-length precursor [37,41,42]. Indeed, several Pr55 Gag domains, such as CA, p2 and NC, contribute to the self-association of the precursor and, as a consequence, to the myristate exposure (Figure 3b) [37]. Accordingly, mutational experiments on these domains inhibiting Pr55 Gag multimerization, impair Pr55 Gag binding to the membrane [37].

(a)

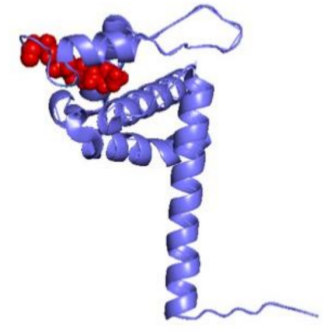

(b)

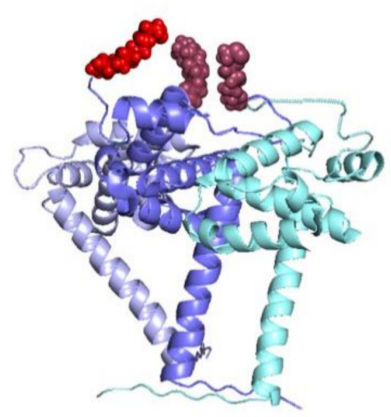

Figure 3. Different structural conformations of HIV-1 MA monomer or trimer. The tertiary structures of the MA domain in the different conformations of the switch look similar. (a) The MA domain in its monomeric conformation (in blue) displays a sequestered myristoyl group (in red) (PDB: 1UPH [36]). (b) Representation of the trimer of MA (in blue, light blue and cyan) and the corresponding exposed myristoyl groups (in red). This model was proposed according to which the myristoyl group is exposed in the multimeric form, thus allowing its interaction with PM (adapted from [37]).

\section{Gag Myristoylation in Other Retroviruses}

The MA domains of retroviral Gag polyproteins display two main roles: they participate in genome incorporation, as several analyses recently pointed out, and they are implicated in membrane association. Interestingly, the majority of the retrovirus family displays a myristoylated MA domain (for reviews see [46-49]).

Among the different genera in which MA is myristoylated, the genus gammaretrovirus is composed by simple and oncogenic retroviruses. One representative virus of this family is MLV inducing leukemias or lymphomas in mice [50]. The MA domain of the primary form of MLV Gag, Pr65 ${ }^{\mathrm{Gag}}$, is myristoylated and contains a polybasic region in its globular domain that interacts electrostatically with $\mathrm{PI}(4,5) \mathrm{P} 2$ at the PM, similarly to HIV-1 [47]. Besides, MLV has the particularity of encoding an additional form of Gag, $\mathrm{gPr} 80^{\mathrm{Gag}}$, which is glycosylated, but not myristoylated, and this last one is involved in the Pr65 Gag trafficking to the PM [51]. However, beside MLV budding at PM, intracellular budding events can also occur into multivesicular bodies (MVBs) or in intracellular compartments as late endosomes in which virus-like particles (VLPs) accumulated [52]. Then, the deltaretrovirus genus contains complex and oncogenic retroviruses, and consists of two different groups, the primate T-lymphotropic viruses (PTLVs) including HTLV-1 and non-primate species, such as BLV [53-55]. Similarly, to MLV, the assembly of those retroviruses can occur at the PM, as well as in intracellular compartments such as late endosomes, MVBs or similar compartments [56]. The myristoylation of MA and the presence of basic amino acids leads to membrane binding and is, in this case, a PI(4,5)P2-independent process [57-59]. Indeed, the HTLV-I viral precursor Pr53 ${ }^{\mathrm{Gag}}$ is able to bind membranes by electrostatic interactions involving the zwitterionic phosphatidylcholines (PC) and the negatively charged phosphatidylserines (PS) contained in endocytic membranes $[57,60]$. Moreover, a model 
was proposed in which the HBR in the HIV-1 MA domain would bind RNA to prevent premature or non-specific binding to cellular membranes [19,20,61]. Interestingly, a similar regulation between MA and RNA was proposed for BLV [62]. Conversely, the lack of this RNA regulation in HTLV-1 could explain the binding of myristoylated MA to the cellular membranes of intracellular compartments [57]. Finally, betaretroviruses show many similarities with lentiviruses, including a myristoylated MA domain [63]. This genus is composed of two groups: the first one is represented by MMTV [64] and by MPMV; and the second one is represented by HERK [65]. Myristoylated-deficient HERK Gag was observed to localize in the nucleus [66]. Contrary to other lentiviruses, NMR structures of MA domains of MPMV [63] and MMTV [67] show that the myristate group is hidden inside the MA in its oligomeric form. These differences suggest that betaretroviruses have developed different strategies to sequester the myristoyl group until the VLP is bound to the PM. At this site, a conformational change, leading to exposure of the myristate group would occur, similarly to other retroviral Mas that bind PM [67].

In contrast, some retroviral Gag precursors are not myristoylated. Indeed, alpharetroviruses represents simple and oncogenic retroviruses like RSV [68]. At the PM, RSV Pr76 Gag interacts with charged lipids PI $(4,5) \mathrm{P} 2$ [38,69], and to ensure proper Pr76 ${ }^{\mathrm{Gag}}$-PM association, the lack of myristoylation is then counterbalanced by electrostatic interactions occurring between the inositol phosphates and a membrane binding domain (MBD), which is composed of basic residues forming a patch of clustered lysines $(K)$ and arginines $(R)$ on the MA surface ([49,68,70], for a review see [71]). Similarly, the MA domain of the lentivirus EIAV [72,73] is not myristoylated, but binds preferentially with phosphatidylinositol 3phosphate (PI(3)P) with a higher affinity compared to PI(4,5)P2 [73,74]. Finally, foamy viruses (FV) as the PFV presents interesting differences compared to HIV-1 ([75], for a review see [76]). In particular, the FV Pr74 ${ }^{\mathrm{Gag}}$ displays a limited number of PTMs compared to the other retroviruses, and strikingly, the FV MA domain contains neither the HBR nor a myristoylation modification. All those elements emphasize a different evolutionary history among retroviruses [75]. Indeed, in this case, viral Env proteins play a major role for viral budding, and the co-expression of Pr74 ${ }^{\mathrm{Gag}}$ with Env is necessary for VLP production [77].

In sum, there are three main distinct strategies used by retroviruses to target membranes for budding. The first one requires the myristate exposure and a highly basic region (HBR) in the MA domain of retroviral precursors to interact with PM. The two others display dispensable myristoylation to achieve proper membrane binding since the hydrophobic interactions are in this case substituted by electrostatic ones produced by a basic domain in the MA, or alternatively by interactions between the precursor and viral elements such as Env proteins.

\section{HIV-1 Pr55 Gag Phosphorylation}

Phosphorylation consists of the addition of a phosphate group to the side chain of amino acids. This PMT modifies the local electrostatic potential of proteins, induces conformational modifications, and affects the protein subcellular localization (for a review see [78], and [79,80]). Kinases, which are the enzymes that catalyze the transfer of phosphate group, have a role at multiple steps of HIV-1 viral, and the inhibition of cellular kinases interacting with HIV-1 at the nuclear level has been shown to affect the viral replication cycle [81]. Among HIV-1 viral proteins, which are phosphorylated, there is Pr55Gag (Table 1 and Figure 4). The MA domain is a substrate for the protein kinase C (PKC) [82], which catalyzes $S$ and $T$ phosphorylation. Several studies identified S111 in HIV-1 MA as the substrate for PKC [82]. Interestingly, substituting S111 with an alanine (A) led to decreased association of Pr55 $5^{\text {Gag }}$ with PM, even though MA was myristoylated. This suggests that PKC could also be involved in membrane binding by regulating the exposure of the myristoyl group [83,84].

Alpha-screen assays allowed us to screen for human kinases interaction with the HIV-1 precursor, and the p6 domain resulted to be a target for PKC. In a further step, mass spectrometry indicated the phosphorylation of $S 488$ residue $[85,86]$. Its substitution with a hydrophobic aromatic residue such as phenylalanine $(\mathrm{F})$, which can occur sponta- 
neously during anti-retroviral treatments, was found to perturb CA-SP1 processing, virus morphogenesis, maturation and virion infectivity [87-89]. On the other hand, the substitution of $\mathrm{S} 488$ by another non phosphorylable residue, such as asparagine $(\mathrm{N})$, displayed no global impact on infectivity, thus suggesting that the production of non-mature viral particles would not be due to the lack of phosphorylation, but by the substitution itself [89]. Moreover, the phosphorylation of the p6 domain was found to be also important for the recruitment of the viral factor Vpr. As a consequence, the inhibition of PKC activity reduced Vpr level in virions, and this affected HIV-1 infectivity [85]. The p6 domain is the main phosphorylated domain in Pr55 Gag and can be phosphorylated at several positions [86,90]. Indeed, phosphoamino acid analysis [90] and mass spectrometry experiments [86] identified several phosphorylated amino acids (Table 1 and Figure 4), that were found to globally promote viral budding [91]. Moreover, electron microscopy analysis revealed that mutation T471A leads to immature viral particles incompletely separated from PM, and immunoblotting analysis showed an incomplete Pr55 Gag proteolytic maturation [91]. In contrast, other findings showed no effects on assembly or on viral release when T471 was substituted with isoleucine (I) or N. Since none of these amino acids can be phosphorylated, it is possible that the observed differences were not due to phosphorylation itself. Furthermore, except for T456 located in the PTAP late domain, the other eleven positions that can be phosphorylated in the p6 domain present redundancy. Mutagenesis experiments confirmed that the modifications of those residues seem to be dispensable for viral release and infectivity [86].

Experiments using an inhibitor of cyclin-dependent kinases [92] showed that also a MAP kinase, the extracellular-signal-regulated kinase 2 (ERK2), is involved in p6 phosphorylation, and this factor can be incorporated into viral particles by interacting with the S148-P149 motif in CA and T471-P472 in p6 [91,93-96] (Table 1, Figure 4). HIV-1 particles without active ERK2 were found to be poorly infectious due to a defect in reverse transcription $[93,95]$. Interestingly, ERK2 phosphorylates other viral proteins including Rev [97], Nef [98], Vif [99,100], and mature MA [95]. Besides, the substitution of four highly conserved and major phospho-acceptor $\mathrm{S}$ residues in the mature MA (Table 1) with A was found to impair viral replication $[95,101]$.

Table 1. Summary of different roles of phosphorylated residues in HIV-1 Pr55Gag.

\begin{tabular}{|c|c|c|c|c|}
\hline Domain & Residue & Enzyme & Observations and Associated (or Proposed) Roles & References \\
\hline \multirow{5}{*}{ MA } & S9 & \multirow{4}{*}{ ERK2 } & & \multirow{4}{*}[95,101]{} \\
\hline & S67 & & Involved in the viral replication & \\
\hline & S72 & & Phosphorylation of the mature form of MA & \\
\hline & S77 & & & \\
\hline & S111 & & $\begin{array}{l}\text { PKC could be involved in membrane binding by regulating the exposure of the } \\
\text { myristoyl group }\end{array}$ & [82-84] \\
\hline \multirow{5}{*}{ CA } & Y132 & Src & $\begin{array}{l}\text { In MA mature } 1 \% \text { of } \mathrm{Y} 132 \text { is phosphorylated } \\
\text { Src overexpression was found to promote the localization of Pr } 55 \text { Gag at the PM }\end{array}$ & {$[102,103]$} \\
\hline & S148 & ERK2 & Belongs to S-P motif involved in recruitment of ERK-2 & [93-96] \\
\hline & \multirow[b]{2}{*}{$\mathrm{T} 456$} & & Belongs to the PTAP late domain & \multirow{2}{*}{ [86] } \\
\hline & & & Potential role in viral infectivity and assembly & \\
\hline & $\mathrm{T} 470$ & & Redundancy with T471, S473, S488, S491, and S499 & [91] \\
\hline \multirow{5}{*}{ p6 } & \multirow{4}{*}{$\mathrm{T} 471$} & \multirow{4}{*}{ ERK-2 } & Belongs to T-P motif involved in the recruitment of ERK-2 & [91] \\
\hline & & & $\begin{array}{l}\text { Its substitution induces the accumulation of immature viral particles } \\
\text { incompletely separated from PM }\end{array}$ & [91] \\
\hline & & & Redundancy with T470, S473, S488, S491, and S499 & [91] \\
\hline & & & Effects on assembly or on viral release is not due to phosphorylation & [86] \\
\hline & S473 & & Redundancy with T470, S471, S491, and S499 & [91] \\
\hline
\end{tabular}


Table 1. Cont.

\begin{tabular}{|c|c|c|c|c|}
\hline Domain & Residue & Enzyme & Observations and Associated (or Proposed) Roles & References \\
\hline & \multirow{6}{*}{ S488 } & \multirow{2}{*}{ ERK2 } & $\begin{array}{l}\text { Viral particles without active ERK2 were found to be poorly infectious due to a } \\
\text { defect in reverse transcription }\end{array}$ & {$[93,95]$} \\
\hline & & & Involved in the phosphorylation of other viral proteins: Rev, Nef, Vif, mature MA & [97-100] \\
\hline & & \multirow{2}{*}{ PKC } & The p6 domain of Pr55Gag is a target for PKC & {$[85,86,90]$} \\
\hline & & & The inhibition of PKC activity reduced Vpr level in virions & {$[85,87,88]$} \\
\hline & & & $\begin{array}{l}\text { Its mutation with F perturbs: } \\
\text { - Viral morphology, maturation and infectivity }\end{array}$ & [87-89] \\
\hline & & & Effects on assembly or on viral release could be not due to phosphorylation & [86] \\
\hline & S491 & & Redundancy with T470, S471, S473, and S499 & [91] \\
\hline & S499 & & Redundancy with T470, S471, S473, and S491 & [91] \\
\hline
\end{tabular}

$\begin{array}{rlllll}1 & \text { MGARASVLSG } & \text { GELDKWEKIR } & \text { LRPGGKKQYK } & \text { LKHIVWASRE } & \text { LERFAVNPGL } \\ 51 & \text { LETSEGCRQI } & \text { LGQLQPSLQT } & \text { GSEELRSLYN } & \text { TIAVLYCVHQ } & \text { RIDVKDTKEA } \\ 101 & \text { LDKIEEEQNK } & \text { SKKKAQQAAA } & \text { DTGNNSQVSQ } & \text { NYPIVQNLQG } & \text { QMVHQAISPR } \\ 151 & \text { TLNAWVKVVE } & \text { EKAFSPEVIP } & \text { MFSALSEGAT } & \text { PQDLNTMLNT } & \text { VGGHQAMQM } \\ 201 & \text { LKETINEEAA } & \text { EWDRLHPVHA } & \text { GPIAPGQMRE } & \text { PRGSDIAGTT } & \text { STLQEQIGWM } \\ 251 & \text { THNPPIPVGE } & \text { IYKRWIILGL } & \text { NKIVRMYSPT } & \text { SILDIRQGPK } & \text { EPFRDYVDRF } \\ 301 & \text { YKTLRAEQAS } & \text { QEVKNWMTET } & \text { LLVQNANPDC } & \text { KTILKALGPG } & \text { ATLEEMMTAC } \\ 351 & \text { QGVGGPGHKA } & \text { RVLAEAMSQV } & \text { TNPATIMIQK } & \text { GNFRNQRKTV } & \text { KCENCGKEGH } \\ 401 & \text { IAKNCRAPRK } & \text { KGCWKCGKEG } & \text { HQMKDCTERQ } & \text { ANFLGKIWPS } & \text { HKGRPGNFLQ } \\ 451 & \text { SRPEPTAPPE } & \text { ESFRFGEETT } & \text { TPSQKQEPID } & \text { KELYPLASLR } & \text { SLFGSDPSSQ } \\ & & & & & \\ \text { Phosphorylation } & & & & & \end{array}$

Figure 4. Phosphorylated residues in HIV-1 Pr55Gag. The different colors represent the Pr55 $5^{\mathrm{Gag}}$ domains, MA (blue), CA (green), spacer peptides p1 and p2 (purple), NC (red), and p6 (black). Phosphorylation positions are highlighted in yellow. TP (in p6) and SP (in CA) motifs involved in the ERK2 recruitment and incorporation into viral particle are indicated in bold [91,93-96].

Finally, the tyrosine kinase Src can also be incorporated into HIV-1 particle [102], and it is involved in the phosphorylation of the tyrosine (Y) 132 in a minority of mature MA proteins. This PMT was shown to play a role in the early phases of HIV-1 replication as the proviral DNA nuclear import [103] and its deletion causes the enhancement of MA accumulation in the cytoplasm at the expense of PM. On the contrary, Src overexpression was found to promote the localization of Pr55 ${ }^{\mathrm{Gag}}$ at the PM [102].

In sum, HIV-1 Pr55Gag is phosphorylated by at least three kinases, PKC, ERK-2 and Src. Interestingly, mutation of phosphorylated residues in the p6 domain revealed that this domain, in addition to MA, can act as membrane targeting domain of Gag [104]. However, phosphorylation positions in 16 mainly display redundancy, thus hindering the evaluation of the impact of each individual phosphorylated residue.

\section{Gag Phosphorylation in Other Retroviruses}

Phosphorylation is a conserved modification in the retroviral family (Table 2). In alpharetroviruses, within the RSV MA domain, a small proportion of $Y$ residues results in being phosphorylated [105], as well as S68 and S106 residues (Table 2). However, S68 seems to be transitionally phosphorylated, while S106 is the main phosphorylated signal [106]. Besides, MA phosphorylation could be involved in the recruitment of factors promoting NC phosphorylation [106,107]. In turn, phosphorylation of S529 in NC was found to be necessary for the specific interaction with gRNA [108], but no other notable effects on assembly, or on infectivity, were observed [106]. 
The deltaretroviruses, HTLV-1 MA is also a phosphoprotein, and S105, which is located close to the two late domains involved in viral release [109], PPPY [110] and PTAP [111], is phosphorylated by ERK-2. Similarly, to HIV-1, ERK-2 is incorporated into HTLV-1 particles, and phosphorylation of the MA domain was found to be involved in virus release and budding efficiency [110].

Interestingly, betaretroviruses such as MPMV encode a phosphoprotein pp24 within the Gag precursor, and its C-terminal cleavage produces the protein pp18 which contains proline-rich motifs (PPPY). Deletion assays indicated that the phosphorylated residue Y205 in pp18 is dispensable for capsid assembly, but is necessary for the viral release [112]. Immunoprecipitation experiments identified the presence of phosphoserines in pp18, [113,114] displaying a redundant character. Similarly, for spumaviruses such as FV, mapping of the p4 domain revealed that seven residues can be phosphorylated (Table 2), but a single substitution of those residues displayed no influence on viral replication [115]. In gammaretrovirus, the phosphorylation of the RNA binding phosphoprotein (p12) within the Gag precursor was found to be necessary for early events of viral life cycle and virion production [116,117]. Mutagenesis experiments identified two residues which can be phosphorylated (S192 and S209). In particular, S192 mainly contributes to p12 phosphorylation and its substitution by A impairs viral assembly and infectivity. However residual phosphorylation can also occur at other positions (Table 2) [117], thus suggesting a redundant character of these modified amino acids. Indeed, the single substitution of one of these residues induced different levels of phosphorylation in p12, displaying no overall effect on the viral cycle [117], even though these PTMs were proposed to modulate p12 early and late functions and p12 viral RNA-binding activity $[117,118]$.

Table 2. Summary of phosphorylated positions in the different domains of retroviral Gag precursors.

\begin{tabular}{|c|c|c|c|c|c|}
\hline Retrovirus & Protein & Residues & Enzyme & Observation and Associated (or Proposed) Roles & References \\
\hline \multirow{4}{*}{ RSV } & \multirow{3}{*}{ MA } & $\begin{array}{l}\text { Y15 } \\
\text { Y46 } \\
\text { S68 }\end{array}$ & PKC & No effect on the viral cycle & {$[105,106]$} \\
\hline & & S106 & PKC & $\begin{array}{l}\text { Major site of phosphorylation } \\
\text { Involved in the recruitment of factors which promote } \\
\text { NC phosphorylation }\end{array}$ & {$[105,106]$} \\
\hline & & Y155 & PKC & No effect on the viral cycle & {$[105,106]$} \\
\hline & $\mathrm{NC}$ & S529 & & Role for the specific interaction with the gRNA & {$[106,107]$} \\
\hline HTLV-1 & MA & S105 & ERK2 & $\begin{array}{l}\text { Close to late domains (PPPY et PTAP) } \\
\text { Involved in viral release and budding efficiency }\end{array}$ & [110] \\
\hline \multirow{3}{*}{ MoMuLV } & \multirow{3}{*}{ p12 } & $\begin{array}{l}\text { S137 } \\
\text { S148 } \\
\text { S150 } \\
\text { S173 }\end{array}$ & & $\begin{array}{l}\text { - Redundancy } \\
\text { - Modulation of early and late functions and the } \\
\text { RNA-binding activity of p12 }\end{array}$ & [117] \\
\hline & & S192 & & $\begin{array}{l}\text { - S192 mainly contributes to p } 12 \text { phosphorylation and its } \\
\text { substitution by A impairs viral assembly and infectivity }\end{array}$ & [117] \\
\hline & & S209 & & & \\
\hline \multirow{2}{*}{ MPMV } & \multirow{2}{*}{ p18 } & Y205 & & $\begin{array}{l}\text { Belongs to proline-rich motif (PPPY) } \\
\text { Necessary for the viral release }\end{array}$ & [112] \\
\hline & & $\begin{array}{l}\text { S167 } \\
\text { S176 } \\
\text { S211 }\end{array}$ & & Redundancy & {$[113,114]$} \\
\hline FV & p4 & $\begin{array}{l}\text { S116 } \\
\text { S119 } \\
\text { S120 } \\
\text { S124 }\end{array}$ & & Redundancy & [115] \\
\hline
\end{tabular}


In conclusion, similarly to HIV-1, the kinases PKC and ERK-2 are the main drivers of retroviral Gag phosphorylation. Interestingly, ERK-2 can be incorporated into the viral particle of HTLV-1. Globally, these PTMs generally seem to play a role in viral particle release and in virus infectivity, even though the impact of the phosphorylation rate in retroviral proteins is complicated by the redundancy of phosphorylated positions.

\section{HIV-1 Pr55 Gag Ubiquitination}

Another crucial PTM for retroviral infectivity is ubiquitination. This PMT consists of intracellular protein modification by adding one or more ubiquitin $(\mathrm{Ub})$ protein(s) (for a review see [119]). Ub is a 76-amino acid polypeptide, which has a conserved structure [120]. The $\mathrm{Ub}$ sequence contains seven $\mathrm{K}$ residues that can be used for subsequent $\mathrm{Ub}$ linkage leading to polyubiquitination (for a review see [121]), even if the two most common polyubiquitination chains consist in the formation of $\mathrm{Ub}$ chain connected to residues $\mathrm{K} 48$ or $\mathrm{K} 63 \mathrm{of} \mathrm{Ub}$. Monoubiquitylation corresponds to a signal for DNA repair, and vesicle sorting or signal transduction, while polyubiquitinated proteins are often targeted to the $26 \mathrm{~S}$ proteasome for degradation, or alternatively involved in regulation of the endocytosis of ESCRT-dependent cargo proteins into Multi Vesicular Bodies (MVB) (for a review see [122]) and DNA damage response [123]. Ubiquitination can be reversed by deubiquitinating enzymes (DUB) [124].

HIV-1 Pr55 Gag is ubiquitinated in its domains at different levels (Table 3 and Figure 5). Indeed, MA, CA, and NC are monoubiquitinated, while p2 can be mono or bi-ubiquitinated [125]. The cumulative mutations of ubiquitin acceptor sites were observed to cause generally budding defects, even if the substitution of $\mathrm{K}$ residues by $\mathrm{R}$ in CA (Table 3 ) revealed very limited effect on viral release, showing that these ubiquitination sites are likely redundant [126]. Besides, it was observed that the level of Pr55 ${ }^{\mathrm{Gag}}$ ubiquitination increases in cellula when a full-length HIV-1 molecular clone is expressed in comparison to a Pr55Gag expression plasmid, suggesting a role of other viral proteins in Pr55 Gag ubiquitination [125]. Globally, the ubiquitination of Pr55 Gag was found to be involved in the viral release and, during HIV-1 assembly, viral particles incorporate free Ub proteins corresponding to about $10 \%$ of the Pr55Gag level, and around $2-5 \%$ of ubiquitinated Pr55 Gag are monoubiquitinated $[125,127-130]$. When the level of free $\mathrm{Ub}$ in cells is reduced by proteasomal inhibition, the number of free $\mathrm{Ub}$ in viral particles and the number of mono-ubiquitinated residues in the p6 domain of Pr55 Gag also decreased [125,127,131]. However free Ub incorporation into viral particles seems to be independent from the global Pr55 ${ }^{\mathrm{Gag}}$ ubiquitination state [132], and the ubiquitination level in virions increased upon overexpression of free $\mathrm{Ub}$ [133]. Furthermore, ubiquitination seems to take place at the PM, and interestingly the level of Pr55 ${ }^{\mathrm{Gag}}$ mono-ubiquitination was found to be directly correlated with ability of the precursor to bind the PM [134].

Table 3. Summary of ubiquitinations in HIV-1 Pr55 ${ }^{\mathrm{Gag}}$ proteins.

\begin{tabular}{cccc}
\hline Domain & Residues & Observation and Associated (or Proposed) Roles & References \\
\hline MA & & Mono-ubiquitination & \\
\hline & K157 & \\
K162 & \\
K202 & \\
K263 & \\
KA & K272 & Mono-ubiquitination & {$[125,126]$} \\
& K290 & Observed redundancy \\
& K302 & \\
& K314 & \\
& K331 & \\
\hline
\end{tabular}


Table 3. Cont.

\begin{tabular}{|c|c|c|c|}
\hline Domain & Residues & Observation and Associated (or Proposed) Roles & References \\
\hline NC & $\begin{array}{l}\text { K388 } \\
\text { K391 } \\
\text { K397 } \\
\text { K403 } \\
\text { K410 } \\
\text { K411 } \\
\text { K415 } \\
\text { K424 }\end{array}$ & Mono-ubiquitination & {$[125,126]$} \\
\hline p2 & $\begin{array}{l}\text { K436 } \\
\text { K442 }\end{array}$ & Mono or di-ubiquitination & {$[125,126]$} \\
\hline \multirow{4}{*}{ p6 } & & $\begin{array}{l}\text { Mono or di-ubiquitination. } \\
\text { Most ubiquitinated domain in } \operatorname{Pr} 55^{\mathrm{Gag}}\end{array}$ & {$[125,126]$} \\
\hline & K475 & $\begin{array}{l}\text { Major target for mono-ubiquitination } \\
\text { No effect in the viral release and infectivity } \\
\text { Involved in global Pr55 } 5 \text { ag ubiquitination }\end{array}$ & {$[125,132]$} \\
\hline & K481 & $\begin{array}{l}\text { Major targets for mono-ubiquitination } \\
\text { No effect on virus release and infectivity } \\
\text { Involved in the global Pr55 Gag ubiquitination }\end{array}$ & {$[125,132]$} \\
\hline & $\mathrm{S} 488 \mathrm{~F}$ & $\begin{array}{l}\text { Conformal changes: formation of a hydrophobic patch } \\
\text { in a-helix at the C-terminus of p6 } \\
\text { Leads to strong interaction of Pr55Gag with the PM } \\
\text { This structure promotes L48 linked polyubiquitination }\end{array}$ & [104] \\
\hline
\end{tabular}

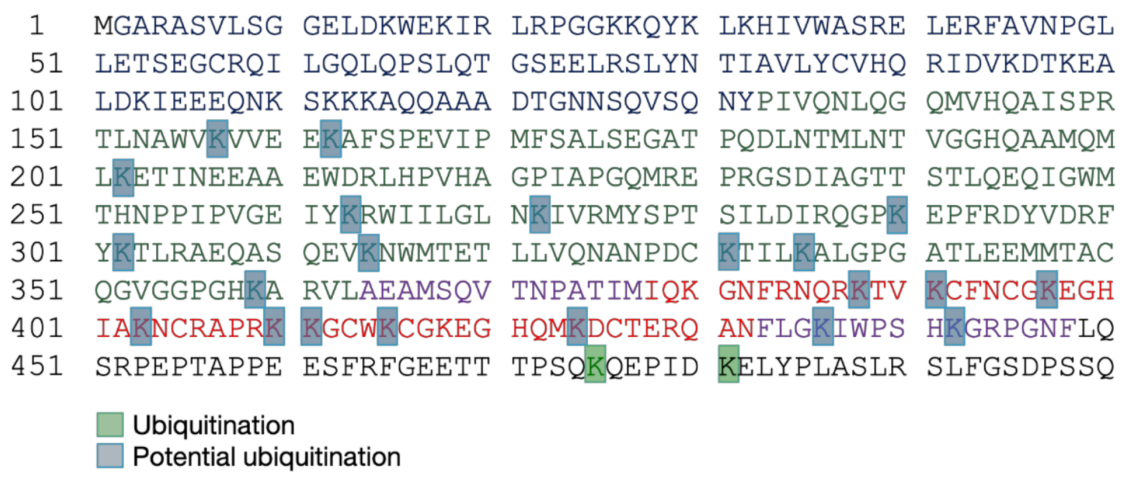

Figure 5. Ubiquitinylated residues in HIV-1 Pr55 ${ }^{\mathrm{Gag}}$. The domains of Pr55 $5^{\mathrm{Gag}}$ are represented by different colors (see Figure 4). Experimentally identified ubiquitinylated positions are highlighted in light green. Potential ubiquitinylated positions are highlighted in light blue.

The C-terminal p6 domain is the most ubiquitinated domain in Pr55Gag [125], and K475 and K481 are the major targets. Even if these mono-ubiquitinated residues are neither directly involved in virus release, nor in infectivity, they were found to be necessary to promote the overall ubiquitination of Pr55 Gag [132]. Besides, the mutation of the highly conserved and phosphorylated S488 residue in p6 domain with F (S488F), which can occur spontaneously during anti-retroviral treatments, has not only an impact on virus morphogenesis, maturation and virion infectivity (Table 1) [87-89], but it can also induce conformal changes in p6, resulting in an enhanced interaction of Pr55Gag with the PM. This would lead to the polyubiquitination of the precursor and consequently to its proteasomal degradation [104].

The p6 domain is known to be involved in the recruitment of host factors, such as Tsg101 (Tumor susceptibility gene 101) and ALIX (ALG-2 interacting protein X), and ubiquitination of those factors strongly promote viral budding [135]. In this frame, fusion 
experiments in which the $\mathrm{p} 6$ domain was coupled with $\mathrm{Ub}$ showed that the affinity of Tsg101 for p6 in this case results in being strengthened [136], and the ubiquitination of Pr55 Gag can increase Tsg101 recruitment [137]. Besides, Tsg101 displays an N-terminal Ub E2 variant (UEV) domain that shows homology with E2 Ub ligases, and that can specifically bind $\mathrm{Ub}$ proteins, as well the PTAP late domain in Pr55 Gag [136]. During assembly, the interaction of Pr55 ${ }^{\mathrm{Gag}}$ with the PM promotes the intermolecular interaction between Tsg101 and the PTAP domain in Pr55Gag [137]. In this conformation, the di-ubiquitinylated K63 of Tsg101 was found to interact with p6, with the consequence of impairing the potential polyubiquitination of the precursor at PM [137].

Finally, the ESCRT-III-associated ALIX protein is also ubiquitinated [128] and specifically interacts with the E3 ubiquitin-protein ligase NEDD4 that can bind the proline-rich retroviral domain PPPY. The interaction between NEDD4 and the retroviral precursor leads to the recruitment of the ESCRT-III complex, including the eukaryotic sucrose non-fermenting protein 7 (Snf7), and the vacuolar protein sorting-associated proteins Vps 2, Vps20 and Vps24, and Vps4 in order to promote retroviral release [138-141]. Since in HIV-1 the PPPY domain is absent, ALIX recruits directly NEDD4 to facilitate this step $[128,129]$.

\section{Gag Ubiquitination in Other Retroviruses}

The role of ubiquitination in the retroviral cycle is not yet fully elucidated. Some retroviruses display a functional contribution of $\mathrm{Ub}$ modifications in virus release such as MLV, MPMV or RSV, and for those viruses, it was shown that, similarly to what observed for HIV-1 [131], the inhibition of proteasome not only induces a reduction of the level of free Ubs in the cytoplasm, but also impairs the release of the viral particles (Table 4) $[127,132,133,142]$. In addition, fusion experiments between RSV Pr76 ${ }^{\text {Gag }}$ and Ub, or overexpression of $\mathrm{Ub}$, displayed an increase in viral particle release [142], thus supporting the idea that ubiquitination of retroviral precursors is crucial for viral budding [133]. However, for other retroviruses such as MMTV or HTLV-1, to date it was not possible to identify a precise role of ubiquitination [127] (Table 4). Besides, the inhibition of the proteasome did not impair the budding of EIAV $[127,143]$. On the other hand, similarly to HIV-1, EIAV particles contain free Ubs corresponding to 10-15\% of Gag proteins. Likewise, the C-terminal p9 domain is mono-ubiquitinated and contains a YPDL late domain which is involved in the recruitment of the ESCRT machinery [143,144]. Moreover, p9 also contains an Ub-like motif (NVKEKD) that may contribute to virus release, thus suggesting alternative release pathways for EIAV even if Ub quantity is low [133,144].

MMTV Gag is monoubiquitinated in its p8 domain, in CA, and is potentially diubiquitinated in NC [127]. In comparison with other retroviruses, MMTV does not contain late domains such as PPPY and PTAP, but an alternative PSAP late domain was found in CA, although its functional role was not yet elucidated. Besides, YXXL motifs, which also represent alternative late domains, were identified in MA and in pp21 viral factor. Importantly, since Gag ubiquitination seem to take place mostly in regions close to the late domains [133], it is possible that the presence of these alternative late domains in EIAV and MMTV precursors promote virus release.

In HLTV-1, more than $40 \%$ of MA are ubiquitinated $[111,145,146]$, and MA can be mono- and di-ubiquitinated [146]. Furthermore, mutagenesis experiments identified K74 in Pr53 $3^{\text {Gag }}$ as the main substrate for ubiquitination [146]. Indeed, substitution experiments in which the K74 is replaced by an R resulted in a decreased release of infectious particles [146]. The ubiquitination of K74 could also play a role in the recruitment of NEDD4 [146], which is also involved, through its interaction with the PPPY late domains, in the release of other retroviruses such as MMPV [112], avian sarcoma virus (ASV) [147], and MLV [132,148]. 
Table 4. Summary of ubiquitinations in the different domains of retroviral Gag proteins.

\begin{tabular}{|c|c|c|c|c|}
\hline Retrovirus & Domain & Residues & Associated (or Proposed) Roles & References \\
\hline \multirow[b]{2}{*}{ HIV } & & & $\begin{array}{l}\text { About } 100 \text { free Ubs are incorporated into viral particles } \\
2-5 \% \text { mono-ubiquitinated }\end{array}$ & {$[130,132-134]$} \\
\hline & & & $\begin{array}{l}\text { Pr55 Gag ubiquitination promotes the virus release } \\
\text { K } 475 \text { and K } 481 \text { in p6 domain are major targets } \\
\text { for ubiquitinations } \\
\text { Pr55 Gag ubiquitination is correlated with the ability of the } \\
\text { precursor to bind the PM }\end{array}$ & {$[132,134]$} \\
\hline \multirow{2}{*}{ MLV } & & & Increases viral release and infectivity & [127] \\
\hline & p12 & & PPPY late domain is involved in the recruitment of NEDD4 & [148] \\
\hline \multirow{3}{*}{ HTLV-1 } & \multirow{3}{*}{ MA } & & Ubiquitination of this domain has a crucial role in release & {$[111,145,146]$} \\
\hline & & & $\begin{array}{l}40 \% \text { of MA are ubiquitinated } \\
\text { MA can be mono- or di-ubiquitinated }\end{array}$ & {$[111,145,146]$} \\
\hline & & K74 & Substrate for Pr53 Gag ubiquitination & [146] \\
\hline MPMV & & & PPPY late domain is involved in the recruitment of NEDD4 & [112] \\
\hline \multirow{2}{*}{ RSV } & & & $\begin{array}{l}\text { - Mono-ubiquitination is crucial for viral release } \\
\text { - Ubiquitylation is required for the recruitment of ESCRT } \\
\text { machinery and for the budding }\end{array}$ & {$[133,143,149]$} \\
\hline & & & $\begin{array}{l}\text { - Contains free Ubs into mature particles } \\
\text { - Pr76 }{ }^{\mathrm{Gag}} \text { mono-ubiquitination is necessary for budding and } \\
\text { to recruit the ESCRT machinery }\end{array}$ & {$[142,149]$} \\
\hline \multirow[b]{3}{*}{ EIAV } & & & $10-15 \%$ of the molar level of the Gag protein of free $\mathrm{Ub}$ & [143] \\
\hline & & & Proteasome inhibition: does not impair the release & [143] \\
\hline & p9 & & $\begin{array}{l}\text { Ub-like motif (NVKEKD) } \\
\text { Mono-ubiquitinated domain } \\
\text { Contains YPDL late domain }\end{array}$ & {$[143,144]$} \\
\hline \multirow{7}{*}{ MMTV } & & & Proteasome inhibition: does not decrease the release & [143] \\
\hline & MA (p10) & & YXXL Late domain & [127] \\
\hline & pp21 & & YXXL Late domain & [127] \\
\hline & p8 & & Mono-ubiquitinated & [127] \\
\hline & \multirow{2}{*}{ CA (p27) } & & Mono-ubiquitinated & [127] \\
\hline & & & PSAP domain & [127] \\
\hline & NC (p14) & & Di-ubiquitinated & [127] \\
\hline PFV & & & Encodes for a very restricted number of $\mathrm{K}$ residues & [150] \\
\hline
\end{tabular}

In RSV particles, more than 100 free Ubs were found [142,149]. However, contrary to other retroviruses, RSV displays free Ubs exclusively into mature viruses [149]. Since Pr76 Gag mono-ubiquitination was found to be necessary for budding and to recruit the ESCRT machinery $[142,149]$, it is thus possible that the presence of free Ubs could be the result of a host-encoded and encapsidated deubiquitinating enzyme (DUB) [124]. Interestingly, this process was also observed to occur during budding or cells lysis [124]. Finally, Gag precursors from spumavirus encode a very limited number of $\mathrm{K}$ residue. This observation suggests that Gag of spumavirus could not be a favorable substrate for the ubiquitination machinery [150].

\section{HIV-1 Pr55 ${ }^{\text {Gag }}$ Sumoylation}

Another modification important for retroviral infectivity is sumoylation, which is a reversible PTM and consists of intracellular protein modification by a covalently attached 
small Ub related modifier (SUMO) protein to a K substrate (for reviews see [151,152]). Even though SUMO is structurally comparable to $\mathrm{Ub}$ (Figure 6a), it presents many differences in amino acids sequence (only 18\% of homology) (Figure 6b) [152]. This PTM is usually involved in the maintenance of genomic integrity, with a role in repair of damaged DNA, and in the regulation of transcription and in gene expression. Like ubiquitination, sumoylation is involved in intracellular signal transduction and can regulate biological processes such as apoptosis, immune response, and carcinogenesis. Besides, sumoylation controls protein localization and it can induce protein conformational changes. SUMOs are highly conserved in eukaryotes, and four SUMO isoforms (SUMO-1 to SUMO-4) are present in mammals [152-154] (Figure 6b). Similarly, to Ub, the C-terminus region of SUMO-1 is linked to $\varepsilon$-amino groups of $\mathrm{K}$ residues in the target protein $[155,156]$. SUMO1 was interestingly found to counterbalance the effect of ubiquitination [157]. SUMO-2 and SUMO-3 are mainly involved in the cellular response to environmental stresses [156] and display very similar sequences with more than $95 \%$ identity $[151,152,156]$. For this reason, they are often named SUMO-2/3. Finally, SUMO-4 is less well known, and its mRNA had been found in few organs such as kidney, spleen, and lymph nodes [152].

To sumoylate a protein, different successive biochemical reactions are required [152,158-160] (Figure 7). Generally, the consensus sequence for K sumoylation is $\psi \mathrm{KXD} / \mathrm{E}(\psi$ stands for a hydrophobic residue). Nevertheless, targets with non-consensus acceptor sites have also been identified [151,152].

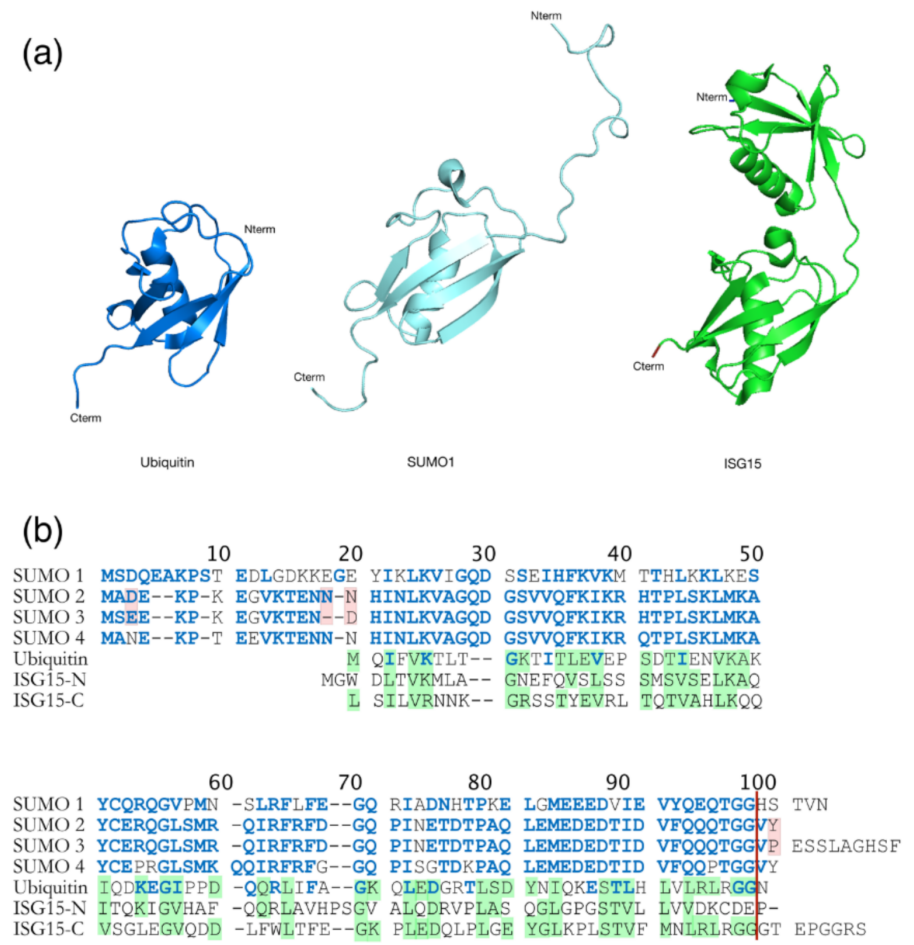

Figure 6. Comparison between $\mathrm{Ub}$ and Ub-like proteins: SUMO and ISG15. (a) Structural comparison between Ub (heavy blue, PDB: 1A5R), SUMO-1 (ligth blue, PDB: 2QHO), and ISG15 (green, PDB: 3PHX). They contain a typical $\beta \beta \alpha \beta \beta \alpha \beta$ fold, even if SUMO-1 has long unstructured $\mathrm{N}$-terminal domain which is absent in Ub. ISG15 is composed with two Ub-like domains in N- (TSG15N) and C- (TSG15C) terminus. (b) Amino acid sequence alignments of Ub, the four SUMO homologs and ISG15 from humans. Identities and similarities are indicated between $\mathrm{Ub}$ and SUMO (blue residues into Ub sequence) and between Ub and ISG15 (shaded green residues in Ub and ISG15). Differences between SUMO-2 and 3 are highlighted in pink. The red vertical line represents the GG end free after the maturation step required for sumoylation. The amino acid sequence homology between SUMO and $\mathrm{Ub}$ is $18 \%$ [152], and $30 \%$ between $\mathrm{Ub}$ and ISG15 [161]. 
The p6 domain of HIV-1 Pr55 $5^{\text {Gag }}$ is sumoylated by SUMO-1, which covalently links K475 in the consensus sequence ( $\psi$ KXE: QKQE) (Table 5$)$. The K475R substitution partially inhibits binding of the precursor to the SUMO-conjugating enzyme E2 (Ubc9) [162], suggesting that more than one Pr55 Gag domain could be involved in the recruitment of Ubc9 $[162,163]$. It was proposed that SUMO-Ubc9 could be involved in intracellular trafficking of Pr55 Gag [164]. Indeed, after translation, the first trafficking complex intermediate observed in the perinuclear region is composed of Pr55 Gag, kinesin family motor 4 (KIF4), Ubc9, and SUMO-1 [164]. In contrast, other studies suggested that the recruitment of Ubc9 would be required for the late stages of viral replication, thus participating to Env incorporation into viral particles [163]. Moreover, the overexpression of SUMO-1 was observed to globally decrease viral infectivity, and sumoylation could be then involved in the negative regulation of viral replication [162]. Interestingly, sumoylation and ubiquitination co-regulate each other [165], and sumoylation and mono-ubiquitination of p6 were both found to occur on K475. It is thus possible that SUMO-1 interaction with p6 protects Pr55 Gag from proteasomal degradation [162]. Overproduction of SUMO-1 should have no direct effect on viral assembly, but if sumoylation competes with ubiquitination, subsequent decrease of Tsg101 recruitment could produce a negative effect on budding [162].

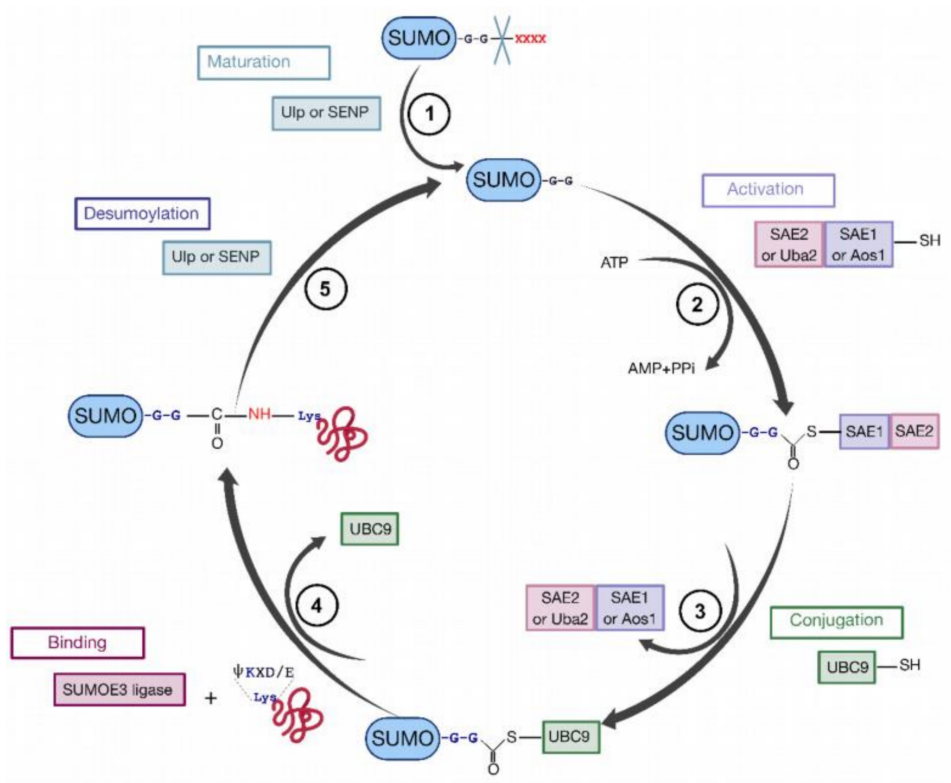

Figure 7. The cycle of sumoylation. This modification is catalyzed by different enzymes and consists in ligation of SUMO protein to K residues of protein substrates. (1) SUMO is maturated by Ub-like specific protease 1 (Ulp1) or human sentrin-specific protease 1 (SENP1). This proteolytic cleavage exposes the C-terminal GG motif required for the activation step. (2) SUMO is activated by a heterodimer composed with SAE1/SAE2 (Aos1/Uba2) to form the SUMO (E1/E2)-activating enzyme. Heterodimer is bound via a thioester bond between the C-terminal G residue of SUMO and the catalytic C of SAE2. (3) SUMO is transferred to the catalytic C of SUMO-conjugating enzyme E2 (or Ubc9) by a transesterification reaction. (4) SUMO is bound to the target protein by Ubc9 in association with SUMO E3 ligase. Ubc9 forms an amide bond between the SUMO C-terminus and $\varepsilon$-amino groups of the acceptor L residues in the target protein. (5) These reactions are reversible by means of the Ulp or SENP proteases.

\section{Gag Sumoylation in Other Retroviruses}

As for HIV-1, other retroviruses are sumoylated (Table 5); however, the impact of sumoylation is not yet fully elucidated. The Ubc9 factor was found to interact with MLV and MPMV Gag proteins [166,167]. Similarly, to HIV-1, in MPMV this factor was suggested to be involved in the trafficking of Pr78 ${ }^{\mathrm{Gag}}$ to the PM [167]. Besides, the CA domain of MoMuLV Gag was shown to interact not only with Ubc9 [168], but also with PIASy, a SUMO E3 ligase [168]. These interactions, leading to CA sumoylation during the early stages of 
the viral life cycle after reverse transcription, might have a role in viral replication [168]. Single K substitutions have generally no effect on the viral cycle, suggesting redundancy between sumoylable positions. On the other hand, the modification of K218 with an R residue was found to reduce the overall viral replication, without affecting the overall SUMO-1 rate on Gag [168].

Table 5. Summary of sumoylated positions in retroviral Gag proteins.

\begin{tabular}{|c|c|c|c|c|}
\hline Retrovirus & Domains & Residues & Associated (or Proposed) Roles & References \\
\hline \multirow{5}{*}{ HIV-1 } & & & Sumoylation and ubiquitination co-regulate each other & [165] \\
\hline & \multirow{4}{*}{ p6 } & & More than one domain should be involved in Ubc9 recruitment & {$[162,163]$} \\
\hline & & & $\begin{array}{l}\text { SUMO-Ubc9 could be involved in intracellular trafficking of Pr55Gag } \\
\text { - in the early phase: perinuclear region or } \\
\text { - in the late stages of replication: potential role in Env incorporation }\end{array}$ & {$[163,164]$} \\
\hline & & \multirow[t]{2}{*}{ K 475} & $\begin{array}{l}\text { Sumoylation could be then involved in the negative regulation of } \\
\text { viral replication }\end{array}$ & [162] \\
\hline & & & $\begin{array}{l}\text { Belongs to QKQE consensus sequence } \\
\text { Sumoylation and mono-ubiquitination of p6 can both occur on K475 }\end{array}$ & [162] \\
\hline MoMuLV & CA & & CA domain of MLV Gag interacts with Ubc9 and with PIASy & [168] \\
\hline MPMV & & & $\begin{array}{l}\text { Recruitment of Ubc9 involved in the active transport of MPMV } \\
\text { Pr78 Gag to the PM }\end{array}$ & [167] \\
\hline RSV & CA & K 244 & $\begin{array}{l}\text { Its substitution with non sumoylable } \mathrm{R} \text { reduces the overall } \\
\text { viral infectivity }\end{array}$ & [142] \\
\hline \multirow{4}{*}{ EIAV } & MA & $\begin{array}{l}\text { K } 13 \\
\text { K } 86 \\
\text { K } 107\end{array}$ & \multirow{3}{*}{ Targets of sumoylation } & \multirow{3}{*}[144,169]{} \\
\hline & CA & $\begin{array}{l}\text { K } 282 \\
\text { K } 297\end{array}$ & & \\
\hline & $\mathrm{NC}$ & $\begin{array}{l}\text { K } 368 \\
\text { K } 373 \\
\text { K } 388 \\
\text { K } 420 \\
\text { K } 423\end{array}$ & & \\
\hline & p9 & K 465 & Constitutes the main target for sumoylation & {$[144,169]$} \\
\hline
\end{tabular}

In the EIAV p9 domain of Gag, K465 is the main target for sumoylation, and mutational experiments showed that this PTM is involved in the regulation of viral replication and infectivity $[144,169]$. Moreover, sumoylation of K465 seems to regulate the sumoylation of other $\mathrm{K}$ residues in different domains of the precursor, such as the MA, the CA and NC (Table 5) [169]. However, a specific role of all those PTMs in viral replication remains to be clarified. Finally, K244 in CA of RSV Pr76 Gag was found to be sumoylated, and its substitution with a non-sumoylable $\mathrm{R}$ residue (K244R) displayed decreased viral infectivity [142].

Similarly, to ubiquitination, the exact role of sumoylation is still a matter of debate and might be different among retroviruses. Moreover, sumoylation is still very difficult to detect, and thus further technological advances will be required to better identify and characterize this PTM.

\section{Retroviral Gag Protein ISGylation}

Besides sumoylation, there exists another Ub-like protein, which is the interferon stimulated gene 15 (ISG15) (for reviews see [161,170]). ISG15 was identified in mammals and corresponds to a $17 \mathrm{kDa}$ protein induced by type I IFN ( $\alpha$ and $\beta)([171,172]$, for a review see [173]) (Figure 8) that contributes to regulation of the cell cycle, and plays a 
role in stress response, signaling transduction, and immune response. The IFN response starts with the binding of type I IFN to cell specific receptors, leading to the activation of the Janus kinase (JAK), the signal transducers and the activators of transcription (STAT) signaling pathway (for a review see [174]), which stimulate the transcription of several hundreds of ISGs, including ISG15. This last one presents a sequence homology with $\mathrm{Ub}$, as it contains two $\mathrm{Ub}$-like domains (Figure 6b). The cycle of ISGylation is comparable with the one of $\mathrm{Ub}$ (Figure 8). Indeed, three distinct biochemical reactions leads the binding between ISG15 and the target protein. This reaction is reversible and the Ub specific peptidase 18 (USP18), also called UBP43, is involved in the reverse reaction, thus acting as an ISG15 deconjugating enzyme [175].

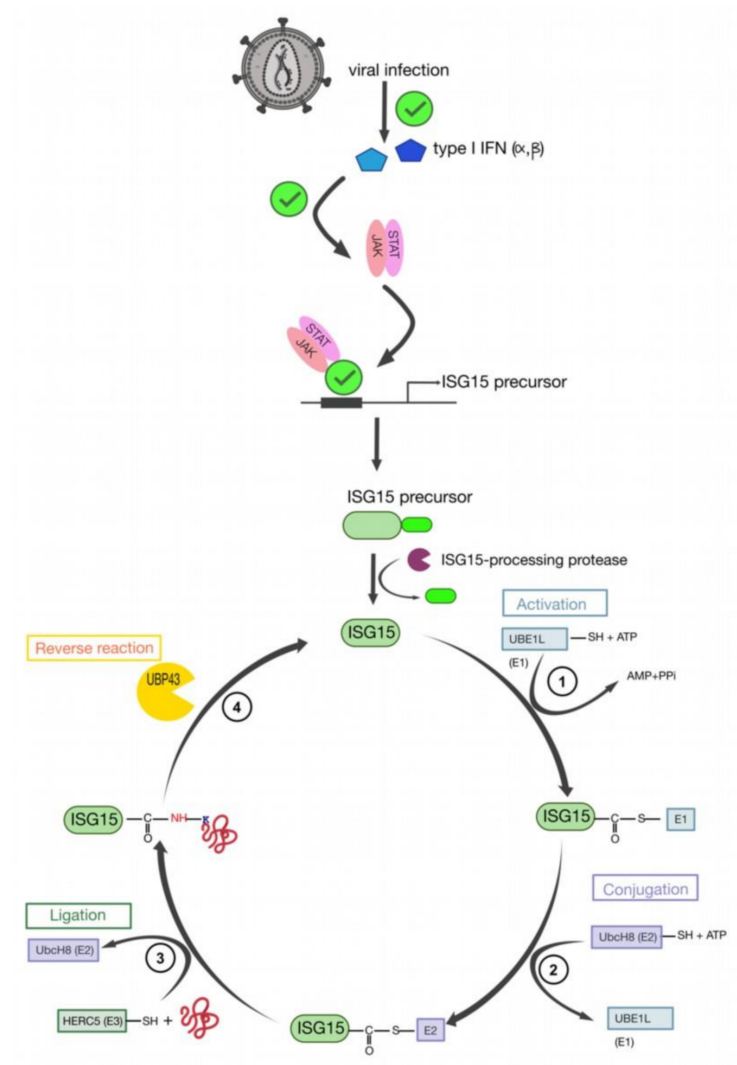

Figure 8. The cycle of ISG15. Viral infection induces the expression of type I IFN. These molecules activate the JAK/STAT signaling pathway, which is responsible for the activation of the ISG15 promoter (for reviews see [161,172]). The ISG15 is maturated by ISG15-specific proteases which cleave the C-terminal extension from ISG15 precursor. (1) The mature ISG15 is activated by UBE1L (E1). It corresponds to the formation of a thioester bond between ISG15 and E1. (2) ISG15 linked to UBE1L is transferred to UbcH8 (E2). (3) Finally, E2 recruits an E3 ligase such as HERC5, transferring the activated $\mathrm{Ub}$ from the $\mathrm{E} 2$ to the $\mathrm{K}$ substrate (ligation reaction). (4) The reaction can be reverted via UBP43. Indeed, it cleaves ISG15 molecules that are conjugated to the substrate proteins via isopeptide bonds (adapted from [161]).

Interestingly, recent studies on HIV-1 gave first information about the role of ISG15 in viral replication. Indeed, suppression of IFN produced by dendritic cell (pDC2) induces the rapid progression of viral infection [176], thus displaying an antiviral role for ISG15. Moreover, in vitro studies showed that ISG15 would inhibit not only the early $[177,178]$ but also the late steps $[179,180]$ of viral replication. The co-transfection with plasmids expressing ISG15 and HIV-1, inhibited the release of viruses, while no impact was seen on HIV-1 proteins production [181]. Moreover, the overexpression of ISG15 and of the activating enzyme UBE1 was observed to impair HIV-1 replication [181]. Interestingly, in these assays, the ubiquitination of Pr55 ${ }^{\mathrm{Gag}}$ and Tsg101 also resulted affected, with the 
consequent abolition of the interactions between the p6 late domain and Tsg101. This impairs the assembly of viral particles and their release, and EM assays showed that immature viruses accumulate of at the PM $[180,181]$. Furthermore, the production of viral particles was also found to be impaired by the E3 ligase HERC5. Interestingly, this inhibition was not found to alter the trafficking of HIV-1 Gag to the PM, but the budding at the PM [180]. Since HERC5 is described to restrict also MLV Gag particle production, it results that HERC5 and more generally, the response ISG15, can be considered as a restrictive factor against retrovirus [180].

In general, ISG15 may affect many other RNA viruses and other retroviruses such as the avian sarcoma leukosis virus (ASLV) (for review see [182]). Similar to HIV-1, ISG15 inhibits the release of ASLV, and the ubiquitination of ASLV Gag precursor. In this context the E3 ubiquitin-protein ligase, NEDD4 was found to maintain its ability to bind the late motif in ASLV Gag [179]. Thus, ISG15 does not seem to prevent directly the interaction between NEDD4 and ASLV Gag, but likely it interferes with the Ub ligase activity of NEDD4, which inhibits ubiquitination [183] even if the precise mechanism remains unclear. Alternatively, it was proposed that the impaired budding of ASLV and HIV-1 could be due to the ISGylation of the ESCRT-III component Charged Multivesicular body Protein 5 (CHMP5) (Figure 9a,b). Indeed, during retroviral budding, the ESCRT-III complex polymerizes at PM in interaction with Pr55Gag. This complex then recruits the inactive dimer form of the ATPase Vps4, which requires it to recruit ATP and its coactivator protein, Vps-associated protein LIP5, to achieve its activated double hexameric-ring structure. This leads to the disassembly of the ESCRT-III complex, thus promoting the viral budding (Figure 9a). According to the proposed model, ISGylation of CHMP5 was found to impair Vps4 binding to LIP5, and thus Vps4 would remain in its inactivated conformation while ESCRT-III complexes would be trapped at the PM, thus blocking virus budding [179] (Figure 9b).

(a)
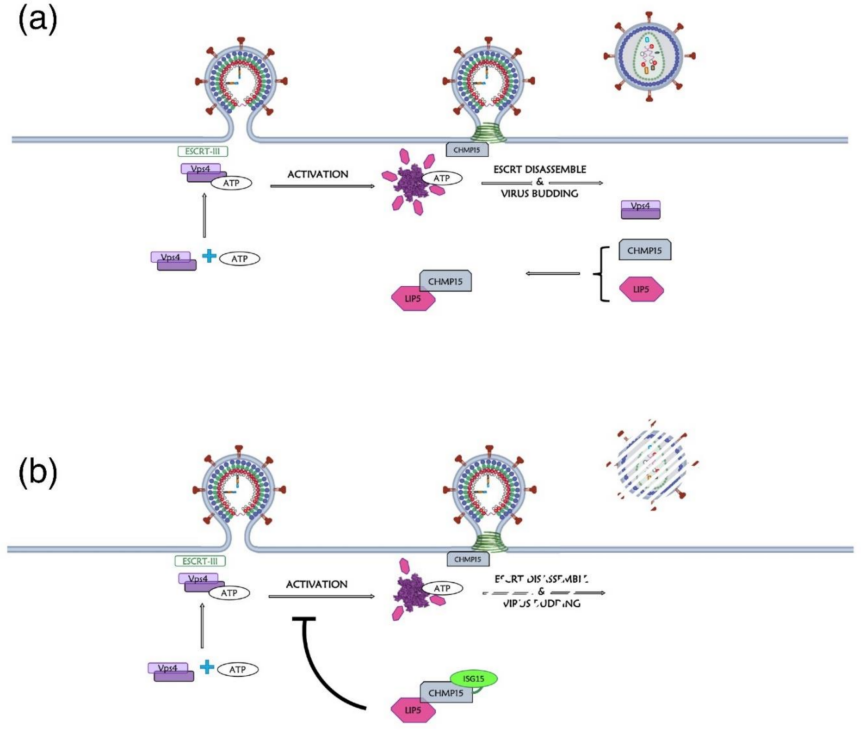

Figure 9. Model of the impact of ISG15 on Vps4 function during retroviral budding. (a) Normal assembly and budding phase during the retroviral cycle. Vps4 activity depends on its oligomeric state. In its dimeric form, Vps4 is cytosolic and inactive. During retrovirus assembly at PM, upon polymerization of the ESCRT-III complex with the p6 domain of HIV-1 Pr55Gag, ATP-bound Vps4 is recruited at the PM. At this step, Vps4 interacts with the coactivator protein LIP5, which is bound to CHMP5, and achieves its double hexameric-ring structure. Then, ATP hydrolysis by the Vps4-LIP5 oligomer releases the ESCRT-III complexes from PM and the dissociation of the ESCRT complex coincides with the membrane fission event that releases retrovirus particles. (b) ISG15 inhibits the budding phase. When CHMP5 is ISGylated, this prevents the interaction between Vps4 and LIP5 by excluding LIP5. In the absence of the Vps4-LIP5 complex, the ESCRT-III complex remains trapped at the PM and the viral release is thus impaired (adapted from [179]). 
Similar mechanisms can occur in the context of other retroviruses [179].

\section{Post-Translational Methylation of Retroviral Gag Proteins}

Finally, retroviral Gag precursors are also subjected to methylation. This covalent PTM is reversible [184]. It consists of the transfer of a methyl group from a donor, the Sadenosylmethionine (SAM), to a target $\mathrm{K}$ residue, and this reaction is catalyzed by the K-methyltransferases (for reviews see [185,186]). The same residue can be mono-, di- or trimethylated, thus conferring a signature which can be specifically recognized by transacting factors named "readers", whose recruitment can promote signaling pathways, regulation of protein-protein interactions, transcription, T-cells activation [187] and subcellular localization [188]. Interestingly, immunoblotting of the CA domain of HIV-1 in presence of AdOx, an inhibitor of methylation, showed an increase of mature CA, suggesting that methylation of HIV-1 Pr55 ${ }^{\mathrm{Gag}}$ could affect proteolytic maturation and likely the viral assembly [189]. The basic region of the NC domain of HIV-1 Pr55 ${ }^{\mathrm{Gag}}$ is also methylated, and this modification was proposed to be involved in the subnuclear localization of the precursor [190]. This same PMT on NC would also decrease the rate of tRNA ${ }^{\text {Lys3 }}$ annealing to the PBS region in gRNA, thus inducing defects in the reverse transcription step [191]. Similarly, the R540 residue in the NC domain of PFV Pr74 ${ }^{\mathrm{Gag}}$ was found to be methylated, and this modification seems to be required for the subnuclear localization of the precursor [192].

\section{Conclusions}

PTMs create a vast diversity in proteins and thus regulate their functions. Globally, PTMs play a role in many processes such as cell signaling, and protein-protein and proteinRNA interactions. Besides, PTMs are crucial for the life cycle of many viruses and the characterization of viral PTMs would provide a better understanding of the mechanisms of viral processes. HIV-1 Pr55 Gag, as many other retroviral Gag precursors, displays several PTMs in its different domains (Figure 10). These PTMs include myristoylation, phosphorylation, ubiquitination, sumoylation, and methylation. All these PTMs can have either antagonistic or cooperative roles, thus allowing fine regulation of the viral cycle. However, up to now, the role of many of these modifications is not fully elucidated and further investigations will be required to better understand their contributions in the viral life cycle. One of the main challenges to study PTMs carried by proteins consists of the development of refined proteomic technologies, allowing the specific detection and characterization of the modifications. The improved knowledge of those regulations would be useful in the future to identify new targets for antiretroviral treatments.

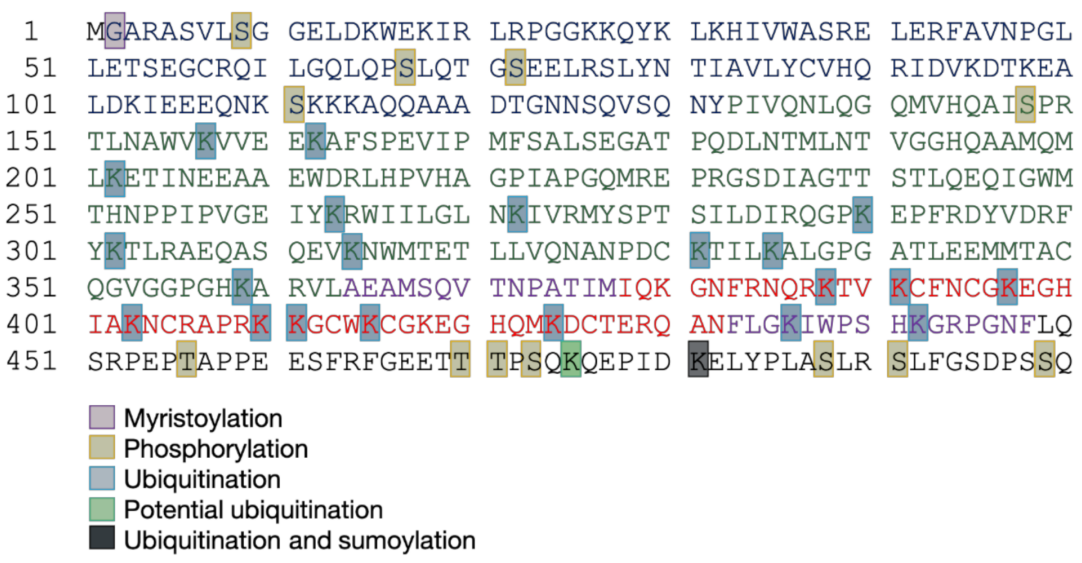

Figure 10. Summary of post-translational modifications of HIV-1 Pr55 Gag residues. The domains of Pr55 $5^{\mathrm{Gag}}$ are represented by different colors (see Figure 4). Experimentally identified modified residues are highlighted: myristoylation (pink), phosphorylation (yellow), ubiquitination (light blue), potential ubiquitinations (light green), and sumoylation (black). 
Author Contributions: S.B. supervised the project; C.B. wrote the manuscript with contributions from S.B., J.-C.P. and R.M. All authors have read and agreed to the published version of the manuscript.

Funding: This work was supported by the Agence Nationale de Recherche sur le SIDA et les hépatites virales (ANRS), SIDACTION and IdEx (Initiative d'Excellence, Université de Strasbourg, France). CB is supported by a fellowship from the French ministry of Research and Higher Education.

Institutional Review Board Statement: Not applicable.

Informed Consent Statement: No applicable.

Data Availability Statement: All figures and discussed literature are available in the main text of this review.

Conflicts of Interest: The authors declare no conflict of interest.

\section{References}

1. Audagnotto, M.; Peraro, M.D. Protein post-translational modifications: In silico prediction tools and molecular modeling. Comput. Struct. Biotechnol. J. 2017, 15, 307-319. [CrossRef]

2. Spoel, S.H. Orchestrating the proteome with post-translational modifications. J. Exp. Bot. 2018, 69, 4499-4503. [CrossRef]

3. Biard-Piechaczyk, M.; Borel, S.; Espert, L.; De Bettignies, G.; Coux, O. HIV-1, ubiquitin and ubiquitin-like proteins: The dialectic interactions of a virus with a sophisticated network of post-translational modifications. Biol. Cell 2012, 104, 165-187. [CrossRef]

4. Chen, L.; Keppler, O.T.; Schölz, C. Post-translational Modification-Based Regulation of HIV Replication. Front. Microbiol. 2018, 9, 2131. [CrossRef] [PubMed]

5. $\quad$ Lu, K.; Heng, X.; Garyu, L.; Monti, S.; Garcia, E.L.; Kharytonchyk, S.; Dorjsuren, B.; Kulandaivel, G.; Jones, S.; Hiremath, A.; et al. NMR Detection of Structures in the HIV-15'-Leader RNA That Regulate Genome Packaging. Science 2011, 334, $242-245$. [CrossRef] [PubMed]

6. Wilkinson, A.K.; Gorelick, R.J.; Vasa, S.M.; Guex, N.; Rein, A.; Mathews, D.H.; Giddings, M.C.; Weeks, K.M. High-Throughput SHAPE Analysis Reveals Structures in HIV-1 Genomic RNA Strongly Conserved across Distinct Biological States. PLoS Biol. 2008, 6, 96. [CrossRef] [PubMed]

7. $\quad$ El-Wahab, E.W.A.; Smyth, R.P.; Mailler, E.; Bernacchi, S.; Vivet-Boudou, V.; Hijnen, M.; Jossinet, F.; Mak, J.; Paillart, J.-C.; Marquet, R. Specific recognition of the HIV-1 genomic RNA by the Gag precursor. Nat. Commun. 2014, 5, 4304. [CrossRef]

8. Smyth, R.P.; Despons, L.; Huili, G.; Bernacchi, S.; Hijnen, M.; Mak, J.; Jossinet, F.; Weixi, L.; Paillart, J.-C.; Von Kleist, M.; et al. Mutational interference mapping experiment (MIME) for studying RNA structure and function. Nat. Methods 2015, 12, 866-872. [CrossRef]

9. Bernacchi, S.; El-Wahab, E.W.A.; Dubois, N.; Hijnen, M.; Smyth, R.P.; Mak, J.; Marquet, R.; Paillart, J.-C. HIV-1 Pr55Gag binds genomic and spliced RNAs with different affinity and stoichiometry. RNA Biol. 2017, 14, 90-103. [CrossRef] [PubMed]

10. Ferrer, M.; Clerté, C.; Chamontin, C.; Basyuk, E.; Lainé, S.; Hottin, J.; Bertrand, E.; Margeat, E.; Mougel, M. Imaging HIV1 RNA dimerization in cells by multicolor super-resolution and fluctuation microscopies. Nucleic Acids Res. 2016, 44, 7922-7934 [CrossRef]

11. Jouvenet, N.; Simon, S.M.; Bieniasz, P.D. Imaging the interaction of HIV-1 genomes and Gag during assembly of individual viral particles. Proc. Natl. Acad. Sci. USA 2009, 106, 19114-19119. [CrossRef]

12. Kutluay, S.B.; Bieniasz, P.D. Analysis of the Initiating Events in HIV-1 Particle Assembly and Genome Packaging. PLoS Pathog. 2010, 6, e1001200. [CrossRef]

13. Mailler, E.; Bernacchi, S.; Marquet, R.; Paillart, J.-C.; Vivet-Boudou, V.; Smyth, R.P. The Life-Cycle of the HIV-1 Gag-RNA Complex. Viruses 2016, 8, 248. [CrossRef] [PubMed]

14. Bieniasz, P.; Telesnitsky, A. Multiple, Switchable Protein:RNA Interactions Regulate Human Immunodeficiency Virus Type 1 Assembly. Annu. Rev. Virol. 2018, 5, 165-183. [CrossRef] [PubMed]

15. Comas-Garcia, M.; Davis, S.R.; Rein, A. On the Selective Packaging of Genomic RNA by HIV-1. Viruses 2016, 8, 246. [CrossRef] [PubMed]

16. Bell, N.M.; Lever, A.M. HIV Gag polyprotein: Processing and early viral particle assembly. Trends Microbiol. 2013, 21, 136-144. [CrossRef] [PubMed]

17. Olety, B.; Ono, A. Roles played by acidic lipids in HIV-1 Gag membrane binding. Virus Res. 2014, 193, 108-115. [CrossRef]

18. Kutluay, S.B.; Zang, T.; Blanco-Melo, D.; Powell, C.; Jannain, D.; Errando, M.; Bieniasz, P.D. Global Changes in the RNA Binding Specificity of HIV-1 Gag Regulate Virion Genesis. Cell 2014, 159, 1096-1109. [CrossRef] [PubMed]

19. Gaines, C.R.; Tkacik, E.; Rivera-Oven, A.; Somani, P.; Achimovich, A.; Alabi, T.; Zhu, A.; Getachew, N.; Yang, A.L.; McDonough, M.; et al. HIV-1 Matrix Protein Interactions with tRNA: Implications for Membrane Targeting. J. Mol. Biol. 2018, 430, $2113-2127$. [CrossRef]

20. Thornhill, D.; Olety, B.; Ono, A. Relationships between MA-RNA Binding in Cells and Suppression of HIV-1 Gag Mislocalization to Intracellular Membranes. J. Virol. 2019, 93, 23. [CrossRef] [PubMed] 
21. Zhao, G.; Perilla, J.R.; Yufenyuy, E.L.; Meng, X.; Chen, B.; Ning, J.; Ahn, J.; Gronenborn, A.M.; Schulten, K.; Aiken, C.; et al. Mature HIV-1 capsid structure by cryo-electron microscopy and all-atom molecular dynamics. Nat. Cell Biol. 2013, 497, 643-646. [CrossRef] [PubMed]

22. Schur, F.K.M.; Hagen, W.J.H.; Rumlová, M.; Ruml, T.; Müller, B.; Kräusslich, H.-G.; Briggs, J.A.G. Structure of the immature HIV-1 capsid in intact virus particles at 8.8 A resolution. Nat. Cell Biol. 2015, 517, 505-508. [CrossRef]

23. Pornillos, O.; Ganser-Pornillos, B.K.; Kelly, B.N.; Hua, Y.; Whitby, F.G.; Stout, C.D.; Sundquist, W.I.; Hill, C.P.; Yeager, M. X-Ray Structures of the Hexameric Building Block of the HIV Capsid. Cell 2009, 137, 1282-1292. [CrossRef]

24. Dannull, J.; Surovoy, A.; Jung, G.; Moelling, K. Specific binding of HIV-1 nucleocapsid protein to PSI RNA in vitro requires $\mathrm{N}$-terminal zinc finger and flanking basic amino acid residues. EMBO J. 1994, 13, 1525-1533. [CrossRef]

25. Webb, J.A.; Jones, C.P.; Parent, L.J.; Rouzina, I.; Musier-Forsyth, K. Distinct binding interactions of HIV-1 Gag to Psi and non-Psi RNAs: Implications for viral genomic RNA packaging. RNA 2013, 19, 1078-1088. [CrossRef] [PubMed]

26. Cimarelli, A.; Sandin, S.; Höglund, S.; Luban, J. Basic Residues in Human Immunodeficiency Virus Type 1 Nucleocapsid Promote Virion Assembly via Interaction with RNA. J. Virol. 2000, 74, 3046-3057. [CrossRef] [PubMed]

27. Ott, D.E.; Coren, L.V.; Shatzer, T. The Nucleocapsid Region of Human Immunodeficiency Virus Type 1 Gag Assists in the Coordination of Assembly and Gag Processing: Role for RNA-Gag Binding in the Early Stages of Assembly. J. Virol. 2009, 83, 7718-7727. [CrossRef]

28. El Meshri, S.E.; Dujardin, D.; Godet, J.; Richert, L.; Boudier, C.; Darlix, J.L.; Didier, P.; Mély, Y.; De Rocquigny, H. Role of the Nucleocapsid Domain in HIV-1 Gag Oligomerization and Trafficking to the Plasma Membrane: A Fluorescence Lifetime Imaging Microscopy Investigation. J. Mol. Biol. 2015, 427, 1480-1494. [CrossRef]

29. Dubois, N.; Khoo, K.K.; Ghossein, S.; Seissler, T.; Wolff, P.; McKinstry, W.J.; Mak, J.; Paillart, J.-C.; Marquet, R.; Bernacchi, S. The C-terminal p6 domain of the HIV-1 Pr55Gag precursor is required for specific binding to the genomic RNA. RNA Biol. 2018, 15, 923-936. [CrossRef]

30. Farazi, T.A.; Waksman, G.; Gordon, J.I. The Biology and Enzymology of ProteinN-Myristoylation. J. Biol. Chem. 2001, 276, 39501-39504. [CrossRef]

31. Martin, D.D.; Beauchamp, E.; Berthiaume, L.G. Post-translational myristoylation: Fat matters in cellular life and death. Biochimie 2011, 93, 18-31. [CrossRef] [PubMed]

32. Dyda, F.; Klein, D.C.; Hickman, A.B. GCN5-Related N-Acetyltransferases: A Structural Overview. Annu. Rev. Biophys. Biomol. Struct. 2000, 29, 81-103. [CrossRef] [PubMed]

33. Johnson, D.R.; Bhatnagar, R.S.; Knoll, L.J.; Gordon, I.J. Genetic and Biochemical Studies of Protein N-Myristoylation. Annu. Rev. Biochem. 1994, 63, 869-914. [CrossRef]

34. Cao, W.; Sumikoshi, K.; Nakamura, S.; Terada, T.; Shimizu, K. Prediction of N-myristoylation modification of proteins by SVM. Bioinformation 2011, 6, 204-206. [CrossRef] [PubMed]

35. Maurer-Stroh, S.; Eisenhaber, B.; Eisenhaber, F. N-terminal N-myristoylation of proteins: Refinement of the sequence motif and its taxon-specific differences 1 1Edited by J. Thornton. J. Mol. Biol. 2002, 317, 523-540. [CrossRef] [PubMed]

36. Tang, C.; Loeliger, E.; Luncsford, P.; Kinde, I.; Beckett, D.; Summers, M.F. Entropic switch regulates myristate exposure in the HIV-1 matrix protein. Proc. Natl. Acad. Sci. USA 2003, 101, 517-522. [CrossRef] [PubMed]

37. Hogue, I.B.; Llewellyn, G.N.; Ono, A. Dynamic Association between HIV-1 Gag and Membrane Domains. Mol. Biol. Int. 2012, 2012, 979765. [CrossRef]

38. Inlora, J.; Collins, D.R.; Trubin, M.E.; Chung, J.Y.J.; Ono, A. Membrane Binding and Subcellular Localization of Retroviral Gag Proteins Are Differentially Regulated by MA Interactions with Phosphatidylinositol-(4,5)-Bisphosphate and RNA. mBio 2014, 5, e02202-14. [CrossRef]

39. Resh, M.D. A myristoyl switch regulates membrane binding of HIV-1 Gag. Proc. Natl. Acad. Sci. USA 2004, 101, 417-418. [CrossRef] [PubMed]

40. Ono, A. Relationships between plasma membrane microdomains and HIV-1 assembly. Biol. Cell 2010, 102, 335-350. [CrossRef] [PubMed]

41. Saad, J.S.; Miller, J.; Tai, J.; Kim, A.; Ghanam, R.H.; Summers, M.F. Structural basis for targeting HIV-1 Gag proteins to the plasma membrane for virus assembly. Proc. Natl. Acad. Sci. USA 2006, 103, 11364-11369. [CrossRef]

42. Saad, J.S.; Loeliger, E.; Luncsford, P.; Liriano, M.; Tai, J.; Kim, A.; Miller, J.; Joshi, A.; Freed, E.O.; Summers, M.F. Point Mutations in the HIV-1 Matrix Protein Turn Off the Myristyl Switch. J. Mol. Biol. 2007, 366, 574-585. [CrossRef] [PubMed]

43. Dalton, A.K.; Ako-Adjei, D.; Murray, P.S.; Murray, D.; Vogt, V.M. Electrostatic Interactions Drive Membrane Association of the Human Immunodeficiency Virus Type 1 Gag MA Domain. J. Virol. 2007, 81, 6434-6445. [CrossRef]

44. Paillart, J.-C.; Göttlinger, H.G. Opposing Effects of Human Immunodeficiency Virus Type 1 Matrix Mutations Support a Myristyl Switch Model of Gag Membrane Targeting. J. Virol. 1999, 73, 2604-2612. [CrossRef] [PubMed]

45. Zhou, W.; Resh, M.D. Differential membrane binding of the human immunodeficiency virus type 1 matrix protein. J. Virol. 1996, 70, 8540-8548. [CrossRef] [PubMed]

46. Murray, P.S.; Li, Z.; Wang, J.; Tang, C.L.; Honig, B.; Murray, D. Retroviral Matrix Domains Share Electrostatic Homology: Models for Membrane Binding Function throughout the Viral Life Cycle. Structure 2005, 13, 1521-1531. [CrossRef] [PubMed]

47. Hamard-Peron, E.; Muriaux, D. Retroviral matrix and lipids, the intimate interaction. Retrovirology 2011, 8, 15. [CrossRef] 
48. Parent, L.J.; Gudleski, N. Beyond Plasma Membrane Targeting: Role of the MA domain of Gag in Retroviral Genome Encapsidation. J. Mol. Biol. 2011, 410, 553-564. [CrossRef] [PubMed]

49. Murray, D.; Ben-Tal, N.; Honig, B.; McLaughlin, S. Electrostatic interaction of myristoylated proteins with membranes: Simple physics, complicated biology. Structure 1997, 5, 985-989. [CrossRef]

50. Kozak, C.A. Origins of the Endogenous and Infectious Laboratory Mouse Gammaretroviruses. Viruses 2014, 7, 1-26. [CrossRef]

51. Nitta, T.; Kuznetsov, Y.; McPherson, A.; Fan, H. Murine leukemia virus glycosylated Gag (gPr80gag) facilitates interferon-sensitive virus release through lipid rafts. Proc. Natl. Acad. Sci. USA 2009, 107, 1190-1195. [CrossRef]

52. Houzet, L.; Gay, B.; Morichaud, Z.; Briant, L.; Mougel, M. Intracellular assembly and budding of the Murine Leukemia Virus in infected cells. Retrovirology 2006, 3, 12. [CrossRef]

53. Hron, T.; Elleder, D.; Gifford, R.J. Deltaretroviruses have circulated since at least the Paleogene and infected a broad range of mammalian species. Retrovirology 2019, 16, 1-7. [CrossRef] [PubMed]

54. Egessain, A.; Ecassar, O. Epidemiological Aspects and World Distribution of HTLV-1 Infection. Front. Microbiol. 2012 , 3, 388. [CrossRef]

55. Barez, P.-Y.; De Brogniez, A.; Carpentier, A.; Gazon, H.; Gillet, N.; Gutiérrez, G.; Hamaidia, M.; Jacques, J.-R.; Perike, S.; Sriramareddy, S.N.; et al. Recent Advances in BLV Research. Viruses 2015, 7, 6080-6088. [CrossRef] [PubMed]

56. Blot, V.; Perugi, F.; Gay, B.; Prévost, M.-C.; Briant, L.; Tangy, F.; Abriel, H.; Staub, O.; Dokhélar, M.-C.; Pique, C. Nedd4.1-mediated ubiquitination and subsequent recruitment of Tsg101 ensure HTLV-1 Gag trafficking towards the multivesicular body pathway prior to virus budding. J. Cell Sci. 2004, 117, 2357-2367. [CrossRef]

57. Inlora, J.; Chukkapalli, V.; Derse, D.; Ono, A. Gag Localization and Virus-Like Particle Release Mediated by the Matrix Domain of Human T-Lymphotropic Virus Type 1 Gag Are Less Dependent on Phosphatidylinositol-(4,5)-Bisphosphate than Those Mediated by the Matrix Domain of HIV-1 Gag. J. Virol. 2011, 85, 3802-3810. [CrossRef] [PubMed]

58. Le Blanc, I.; Rosenberg, A.R.; Dokhélar, M.-C. Multiple Functions for the Basic Amino Acids of the Human T-Cell Leukemia Virus Type 1 Matrix Protein in Viral Transmission. J. Virol. 1999, 73, 1860-1867. [CrossRef]

59. Fogarty, K.H.; Zhang, W.; Grigsby, I.F.; Johnson, J.L.; Chen, Y.; Mueller, J.D.; Mansky, L.M. New Insights into HTLV-1 Particle Structure, Assembly, and Gag-Gag Interactions in Living Cells. Viruses 2011, 3, 770-793. [CrossRef] [PubMed]

60. Yeung, T.; Gilbert, G.E.; Shi, J.; Silvius, J.; Kapus, A.; Grinstein, S. Membrane Phosphatidylserine Regulates Surface Charge and Protein Localization. Science 2008, 319, 210-213. [CrossRef]

61. Chukkapalli, V.; Oh, S.J.; Ono, A. Opposing mechanisms involving RNA and lipids regulate HIV-1 Gag membrane binding through the highly basic region of the matrix domain. Proc. Natl. Acad. Sci. USA 2010, 107, 1600-1605. [CrossRef] [PubMed]

62. Wang, H.; Norris, K.M.; Mansky, L.M. Involvement of the Matrix and Nucleocapsid Domains of the Bovine Leukemia Virus Gag Polyprotein Precursor in Viral RNA Packaging. J. Virol. 2003, 77, 9431-9438. [CrossRef]

63. Prchal, J.; Srb, P.; Hunter, E.; Ruml, T.; Hrabal, R. The Structure of Myristoylated Mason-Pfizer Monkey Virus Matrix Protein and the Role of Phosphatidylinositol-(4,5)-Bisphosphate in Its Membrane Binding. J. Mol. Biol. 2012, 423, 427-438. [CrossRef]

64. Ross, S.R. Mouse Mammary Tumor Virus Molecular Biology and Oncogenesis. Viruses 2010, 2, 2000-2012. [CrossRef] [PubMed]

65. Hayward, A.J.; Tachedjian, M.; Cui, J.; Field, H.; Holmes, E.C.; Wang, L.-F.; Tachedjian, G. Identification of diverse full-length endogenous betaretroviruses in megabats and microbats. Retrovirology 2013, 10, 35. [CrossRef] [PubMed]

66. Monde, K.; Contreras-Galindo, R.; Kaplan, M.H.; Markovitz, D.M.; Ono, A. Human Endogenous Retrovirus K Gag Coassembles with HIV-1 Gag and Reduces the Release Efficiency and Infectivity of HIV-1. J. Virol. 2012, 86, 11194-11208. [CrossRef]

67. Doležal, M.; Zábranský, A.; Dostál, J.; Vaněk, O.; Brynda, J.; Lepšík, M.; Hadravová, R.; Pichová, I. Myristoylation drives dimerization of matrix protein from mouse mammary tumor virus. Retrovirology 2016, 13, 1-15. [CrossRef]

68. Dalton, A.K.; Murray, P.S.; Murray, D.; Vogt, V.M. Biochemical Characterization of Rous Sarcoma Virus MA Protein Interaction with Membranes. J. Virol. 2005, 79, 6227-6238. [CrossRef]

69. Nadaraia-Hoke, S.; Bann, D.V.; Lochmann, T.L.; Gudleski-O’Regan, N.; Parent, L.J. Alterations in the MA and NC Domains Modulate Phosphoinositide-Dependent Plasma Membrane Localization of the Rous Sarcoma Virus Gag Protein. J. Virol. 2013, 87, 3609-3615. [CrossRef] [PubMed]

70. Callahan, E.M.; Wills, J.W. Repositioning Basic Residues in the M Domain of the Rous Sarcoma Virus Gag Protein. J. Virol. 2000, 74, 11222-11229. [CrossRef]

71. Dick, R.A.; Vogt, V.M. Membrane interaction of retroviral Gag proteins. Front. Microbiol. 2014, 5, 187. [CrossRef]

72. Hatanaka, H.; Iourin, O.; Rao, Z.; Fry, E.; Kingsman, A.; Stuart, D.I. Structure of Equine Infectious Anemia Virus Matrix Protein. J. Virol. 2002, 76, 1876-1883. [CrossRef] [PubMed]

73. Zhang, Z.; Ma, J.; Zhang, X.; Su, C.; Yao, Q.-C.; Wang, X. Equine Infectious Anemia Virus Gag Assembly and Export Are Directed by Matrix Protein throughtrans-Golgi Networks and Cellular Vesicles. J. Virol. 2015, 90, 1824-1838. [CrossRef]

74. Fernandes, F.; Chen, K.; Ehrlich, L.S.; Jin, J.; Chen, M.H.; Medina, G.N.; Symons, M.; Montelaro, R.; Donaldson, J.; Tjandra, N.; et al. Phosphoinositides Direct Equine Infectious Anemia Virus Gag Trafficking and Release. Traffic 2010, 12, 438-451. [CrossRef]

75. Goldstone, D.C.; Flower, T.G.; Ball, N.J.; Sanz-Ramos, M.; Yap, M.W.; Ogrodowicz, R.W.; Stanke, N.; Reh, J.; Lindemann, D.; Stoye, J.P.; et al. A Unique Spumavirus Gag N-terminal Domain with Functional Properties of Orthoretroviral Matrix and Capsid. PLoS Pathog. 2013, 9, e1003376. [CrossRef]

76. Heneine, W.; Schweizer, M.; Sandstrom, P.; Folks, T. Human Infection with Foamy Viruses. Curr. Top. Microbiol. Immunol. 2003, 277, 181-196. [CrossRef] [PubMed] 
77. Shaw, K.L.; Lindemann, D.; Mulligan, M.J.; Goepfert, P.A. Foamy Virus Envelope Glycoprotein Is Sufficient for Particle Budding and Release. J. Virol. 2003, 77, 2338-2348. [CrossRef] [PubMed]

78. Nishi, H.; Shaytan, A.; Panchenko, A.R. Physicochemical mechanisms of protein regulation by phosphorylation. Front. Genet. 2014, 5, 270. [CrossRef] [PubMed]

79. Mandell, D.J.; Chorny, I.; Groban, E.S.; Wong, S.E.; Levine, E.; Rapp, A.C.S.; Jacobson, M.P. Strengths of Hydrogen Bonds Involving Phosphorylated Amino Acid Side Chains. J. Am. Chem. Soc. 2007, 129, 820-827. [CrossRef] [PubMed]

80. Burnett, G.; Kennedy, E.P. The Enzymatic Phosphorylation of Proteins. J. Biol. Chem. 1954, 211, 969-980. [CrossRef]

81. Francis, A.C.; Di Primio, C.; Allouch, A.; Cereseto, A. Role of phosphorylation in the nuclear biology of HIV-1. Curr. Med. Chem. 2011, 18, 2904-2912. [CrossRef] [PubMed]

82. Burnette, B.; Yu, G.; Felsted, R. Phosphorylation of HIV-1 gag proteins by protein kinase C. J. Biol. Chem. 1993, 268, 8698-8703. [CrossRef]

83. Yu, G.; Shen, F.S.; Sturch, S.; Aquino, A.; Glazer, R.I.; Felsted, R.L. Regulation of HIV-1 gag Protein Subcellular Targeting by Protein Kinase C. J. Biol. Chem. 1995, 270, 4792-4796. [CrossRef] [PubMed]

84. Kräusslich, H.G. Morphogenesis and Maturation of Retroviruses-Google Livres, 1st ed.; Springer Science \& Business Media: Berlin/Heidelberg, Germany, 1996.

85. Kudoh, A.; Takahama, S.; Sawasaki, T.; Ode, H.; Yokoyama, M.; Okayama, A.; Ishikawa, A.; Miyakawa, K.; Matsunaga, S.; Kimura, H.; et al. The phosphorylation of HIV-1 Gag by atypical protein kinase $\mathrm{C}$ facilitates viral infectivity by promoting Vpr incorporation into virions. Retrovirology 2014, 11, 9. [CrossRef] [PubMed]

86. Radestock, B.; Morales, I.; Rahman, S.A.; Radau, S.; Glass, B.; Zahedi, R.P.; Müller, B.; Kräusslich, H.-G. Comprehensive Mutational Analysis Reveals p6Gag Phosphorylation to Be Dispensable for HIV-1 Morphogenesis and Replication. J. Virol. 2012, 87, 724-734. [CrossRef]

87. Votteler, J.; Neumann, L.; Hahn, S.; Hahn, F.; Rauch, P.; Schmidt, K.; Studtrucker, N.; Solbak, S.M.; Fossen, T.; Henklein, P.; et al. Highly conserved serine residue 40 in HIV-1 p6 regulates capsid processing and virus core assembly. Retrovirology $2011,8,11$. [CrossRef] [PubMed]

88. Watanabe, S.M.; Chen, M.-H.; Khan, M.; Ehrlich, L.; Kemal, K.S.; Weiser, B.; Shi, B.; Chen, C.; Powell, M.; Anastos, K.; et al. The S40 residue in HIV-1 Gag p6 impacts local and distal budding determinants, revealing additional late domain activities. Retrovirology 2013, 10, 143. [CrossRef]

89. Radestock, B.; Burk, R.; Müller, B.; Kräusslich, H.-G. Re-visiting the functional Relevance of the highly conserved Serine 40 Residue within HIV-1 p6Gag. Retrovirology 2014, 11, 1-5. [CrossRef]

90. Müller, B.; Patschinsky, T.; Kräusslich, H.-G. The Late-Domain-Containing Protein p6 Is the Predominant Phosphoprotein of Human Immunodeficiency Virus Type 1 Particles. J. Virol. 2002, 76, 1015-1024. [CrossRef]

91. Hemonnot, B.; Cartier, C.; Gay, B.; Rebuffat, S.; Bardy, M.; Devaux, C.; Boyer, V.; Briant, L. The Host Cell MAP Kinase ERK2 Regulates Viral Assembly and Release by Phosphorylating the p6 Protein of HIV-1. J. Biol. Chem. 2004, 279, 32426-32434. [CrossRef]

92. Wang, Z.; Canagarajah, B.J.; Boehm, J.C.; Kassisà, S.; Cobb, M.H.; Young, P.R.; Abdel-Meguid, S.; Adams, J.L.; Goldsmith, E.J. Structural basis of inhibitor selectivity in MAP kinases. Structure 1998, 6, 1117-1128. [CrossRef]

93. Cartier, C.; Deckert, M.; Grangeasse, C.; Trauger, R.; Jensen, F.; Bernard, A.; Cozzone, A.; Desgranges, C.; Boyer, V. Association of ERK2 mitogen-activated protein kinase with human immunodeficiency virus particles. J. Virol. 1997, 71, 4832-4837. [CrossRef]

94. Cartier, C.; Hemonnot, B.; Gay, B.; Bardy, M.; Sanchiz, C.; Devaux, C.; Briant, L. Active cAMP-dependent Protein Kinase Incorporated within Highly Purified HIV-1 Particles Is Required for Viral Infectivity and Interacts with Viral Capsid Protein. J. Biol. Chem. 2003, 278, 35211-35219. [CrossRef]

95. Jacqué, J.; Mann, A.; Enslen, H.; Sharova, N.; Brichacek, B.; Davis, R.J.; Stevenson, M. Modulation of HIV-1 infectivity by MAPK, a virion-associated kinase. EMBO J. 1998, 17, 2607-2618. [CrossRef]

96. Dochi, T.; Nakano, T.; Inoue, M.; Takamune, N.; Shoji, S.; Sano, K.; Misumi, S. Phosphorylation of human immunodeficiency virus type 1 capsid protein at serine 16, required for peptidyl-prolyl isomerase-dependent uncoating, is mediated by virion-incorporated extracellular signal-regulated kinase 2. J. Gen. Virol. 2014, 95, 1156-1166. [CrossRef] [PubMed]

97. Yang, X.; Gabuzda, D. Regulation of Human Immunodeficiency Virus Type 1 Infectivity by the ERK Mitogen-Activated Protein Kinase Signaling Pathway. J. Virol. 1999, 73, 3460-3466. [CrossRef]

98. Greenway, A.; Azad, A.; Mills, J.; McPhee, D. Human immunodeficiency virus type 1 Nef binds directly to Lck and mitogenactivated protein kinase, inhibiting kinase activity. J. Virol. 1996, 70, 6701-6708. [CrossRef] [PubMed]

99. Yang, X.; Goncalves, J.; Gabuzda, D. Phosphorylation of Vif and Its Role in HIV-1 Replication. J. Biol. Chem. 1996, 271, 10121-10129. [CrossRef] [PubMed]

100. Yang, X.; Gabuzda, D. Mitogen-activated Protein Kinase Phosphorylates and Regulates the HIV-1 Vif Protein. J. Biol. Chem. 1998, 273, 29879-29887. [CrossRef]

101. Kaushik, R.; Ratner, L. Role of Human Immunodeficiency Virus Type 1 Matrix Phosphorylation in an Early Postentry Step of Virus Replication. J. Virol. 2004, 78, 2319-2326. [CrossRef] [PubMed]

102. Strasner, A.B.; Natarajan, M.; Doman, T.; Key, D.; August, A.; Henderson, A.J. The Src Kinase Lck Facilitates Assembly of HIV-1 at the Plasma Membrane. J. Immunol. 2008, 181, 3706-3713. [CrossRef] 
103. Gallay, P.; Swingler, S.; Song, J.; Bushman, F.; Trono, D. HIV nuclear import is governed by the phosphotyrosine-mediated binding of matrix to the core domain of integrase. Cell 1995, 83, 569-576. [CrossRef]

104. Hahn, F.; Setz, C.; Friedrich, M.; Rauch, P.; Solbak, S.M.; Frøystein, N.Å.; Henklein, P.; Votteler, J.; Fossen, T.; Schubert, U. Mutation of the Highly Conserved Ser-40 of the HIV-1 p6 Gag Protein to Phe Causes the Formation of a Hydrophobic Patch, Enhances Membrane Association, and Polyubiquitination of Gag. Viruses 2014, 6, 3738-3765. [CrossRef] [PubMed]

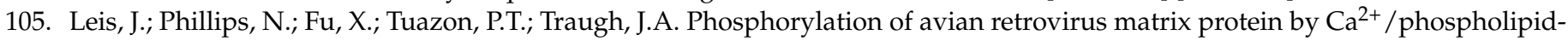
dependent protein kinase. JBIC J. Biol. Inorg. Chem. 1989, 179, 415-422. [CrossRef] [PubMed]

106. Nelle, T.D.; Verderame, M.F.; Leis, J.; Wills, J.W. The Major Site of Phosphorylation within the Rous Sarcoma Virus MA Protein Is Not Required for Replication. J. Virol. 1998, 72, 1103-1107. [CrossRef] [PubMed]

107. Pepinsky, R.B.; Papayannopoulos, A.I.; Campbell, S.; Vogt, V.M. Analysis of Rous sarcoma virus Gag protein by mass spectrometry indicates trimming by host exopeptidase. J. Virol. 1996, 70, 3313-3318. [CrossRef]

108. Fu, X.; Tuazon, P.T.; Traugh, J.A.; Leis, J. Site-Directed Mutagenesis of the Avian Retrovirus Nucleocapsid Protein, Pp12, at Serine 40, the Primary Site of Phosphorylation in Vivo. J. Biol. Chem. 1988, 268, 2134-2139. [CrossRef]

109. Wang, H.; Machesky, N.J.; Mansky, L.M. Both the PPPY and PTAP Motifs Are Involved in Human T-Cell Leukemia Virus Type 1 Particle Release. J. Virol. 2004, 78, 1503-1512. [CrossRef] [PubMed]

110. Hemonnot, B.; Molle, D.; Bardy, M.; Gay, B.; Laune, D.; Devaux, C.; Briant, L. Phosphorylation of the HTLV-1 matrix L-domaincontaining protein by virus-associated ERK-2 kinase. Virology 2006, 349, 430-439. [CrossRef]

111. Bouamr, F.; Melillo, J.A.; Wang, M.Q.; Nagashima, K.; Santos, M.D.L.; Rein, A.; Goff, S.P. PPPYEPTAP Motif Is the Late Domain of Human T-Cell Leukemia Virus Type 1 Gag and Mediates Its Functional Interaction with Cellular Proteins Nedd4 and Tsg101. J. Virol. 2003, 77, 11882-11895. [CrossRef]

112. Yasuda, J.; Hunter, E. A Proline-Rich Motif (PPPY) in the Gag Polyprotein of Mason-Pfizer Monkey Virus Plays a MaturationIndependent Role in Virion Release. J. Virol. 1998, 72, 4095-4103. [CrossRef]

113. Henderson, E.L.; Sowder, R.; Smythers, G.; Benveniste, R.E.; Oroszlan, S. Purification and N-terminal amino acid sequence comparisons of structural proteins from retrovirus-D/Washington and Mason-Pfizer monkey virus. J. Virol. 1985, 55, 778-787. [CrossRef] [PubMed]

114. Uckert, W.; Wunderlich, V.; Fiebach, H.; Hertling, I.; Stein, U.; Kraft, R.; Desrosiers, R. Biochemical and immunological characterization of structural proteins from retrovirus-D/New England and comparison to Mason-Pfizer monkey virus and permanent human fibroblast virus. Arch. Virol. 1987, 94, 267-282. [CrossRef]

115. Enssle, J.; Fischer, N.; Moebes, A.; Mauer, B.; Smola, U.; Rethwilm, A. Carboxy-terminal cleavage of the human foamy virus Gag precursor molecule is an essential step in the viral life cycle. J. Virol. 1997, 71, 7312-7317. [CrossRef]

116. Yuan, B.; Li, X.; Goff, S.P. Mutations altering the moloney murine leukemia virus p12 Gag protein affect virion production and early events of the virus life cycle. EMBO J. 1999, 18, 4700-4710. [CrossRef] [PubMed]

117. Yueh, A.; Goff, S.P. Phosphorylated Serine Residues and an Arginine-Rich Domain of the Moloney Murine Leukemia Virus p12 Protein Are Required for Early Events of Viral Infection. J. Virol. 2003, 77, 1820-1829. [CrossRef]

118. Brzezinski, J.D.; Felkner, R.; Modi, A.; Liu, M.; Roth, M.J. Phosphorylation Requirement of Murine Leukemia Virus p12. J. Virol. 2016, 90, 11208-11219. [CrossRef] [PubMed]

119. Callis, J. The Ubiquitination Machinery of the Ubiquitin System. Arab. Book 2014, 12, e0174. [CrossRef]

120. Vijay-Kumar, S.; Bugg, C.; Wilkinson, K.; Vierstra, R.; Hatfield, P.; Cook, W. Comparison of the three-dimensional structures of human, yeast, and oat ubiquitin. J. Biol. Chem. 1987, 262, 6396-6399. [CrossRef]

121. Komander, D. The emerging complexity of protein ubiquitination. Biochem. Soc. Trans. 2009, 37, 937-953. [CrossRef]

122. Shields, S.B.; Piper, R.C. How Ubiquitin Functions with ESCRTs. Traffic 2011, 12, 1306-1317. [CrossRef]

123. Ohtake, F.; Saeki, Y.; Ishido, S.; Kanno, J.; Tanaka, K. The K48-K63 Branched Ubiquitin Chain Regulates NF-кB Signaling. Mol. Cell 2016, 64, 251-266. [CrossRef] [PubMed]

124. Suresh, B.; Lee, J.; Kim, K.-S.; Ramakrishna, S. The Importance of Ubiquitination and Deubiquitination in Cellular Reprogramming. Stem Cells Int. 2016, 2016, 1-14. [CrossRef] [PubMed]

125. Gottwein, E.; Kräusslich, H.-G. Analysis of Human Immunodeficiency Virus Type 1 Gag Ubiquitination. J. Virol. 2005, 79, 9134-9144. [CrossRef]

126. Gottwein, E.; Jäger, S.; Habermann, A.; Kräusslich, H.-G. Cumulative Mutations of Ubiquitin Acceptor Sites in Human Immunodeficiency Virus Type 1 Gag Cause a Late Budding Defect. J. Virol. 2006, 80, 6267-6275. [CrossRef]

127. Ott, D.E.; Coren, L.V.; Ii, R.C.S.; Adams, J.; Schubert, U. Retroviruses Have Differing Requirements for Proteasome Function in the Budding Process. J. Virol. 2003, 77, 3384-3393. [CrossRef] [PubMed]

128. Sette, P.; Jadwin, J.A.; Dussupt, V.; Bello, N.F.; Bouamr, F. The ESCRT-Associated Protein Alix Recruits the Ubiquitin Ligase Nedd4-1 To Facilitate HIV-1 Release through the LYPXnL L Domain Motif. J. Virol. 2010, 84, 8181-8192. [CrossRef]

129. Sette, P.; Nagashima, K.; Piper, R.C.; Bouamr, F. Ubiquitin conjugation to Gag is essential for ESCRT-mediated HIV-1 budding. Retrovirology 2013, 10, 79. [CrossRef] [PubMed]

130. Ott, D.E.; Coren, L.V.; Copeland, T.D.; Kane, B.P.; Johnson, D.G.; Sowder, R.C.; Yoshinaka, Y.; Oroszlan, S.; Arthur, L.O.; Henderson, L.E. Ubiquitin Is Covalently Attached to the p6GagProteins of Human Immunodeficiency Virus Type 1 and Simian Immunodeficiency Virus and to the p12Gag Protein of Moloney Murine Leukemia Virus. J. Virol. 1998, 72, 2962-2968. [CrossRef] 
131. Schubert, U.; Ott, D.E.; Chertova, E.N.; Welker, R.; Tessmer, U.; Princiotta, M.F.; Bennink, J.R.; Kräusslich, H.-G.; Yewdell, J.W. Proteasome inhibition interferes with Gag polyprotein processing, release, and maturation of HIV-1 and HIV-2. Proc. Natl. Acad. Sci. USA 2000, 97, 13057-13062. [CrossRef] [PubMed]

132. Ott, D.E.; Coren, L.V.; Chertova, E.N.; Gagliardi, T.D.; Schubert, U. Ubiquitination of HIV-1 and MuLV Gag. Virology 2000, 278, 111-121. [CrossRef]

133. Patnaik, A.; Chau, V.; Wills, J.W. Ubiquitin is part of the retrovirus budding machinery. Proc. Natl. Acad. Sci. USA 2000, 97, 13069-13074. [CrossRef]

134. Jäger, S.; Gottwein, E.; Kräusslich, H.-G. Ubiquitination of Human Immunodeficiency Virus Type 1 Gag Is Highly Dependent on Gag Membrane Association. J. Virol. 2007, 81, 9193-9201. [CrossRef] [PubMed]

135. Von Schwedler, U.K.; Stuchell, M.; Müller, B.; Ward, D.M.; Chung, H.Y.; Morita, E.; Wang, H.E.; Davis, T.; He, G.P.; Cimbora, D.M.; et al. The protein network of HIV budding. Cell 2003, 114, 701-713. [CrossRef]

136. Pornillos, O.; Alam, S.L.; Rich, R.L.; Myszka, D.G.; Davis, D.R.; Sundquist, W.I. Structure and functional interactions of the Tsg101 UEV domain. EMBO J. 2002, 21, 2397-2406. [CrossRef]

137. Watanabe, S.M.; Strickland, M.; Tjandra, N.; Carter, C.A. RNA Binding Suppresses Tsg101 Recognition of Ub-Modified Gag and Facilitates Recruitment to the Plasma Membrane. Viruses 2020, 12, 447. [CrossRef]

138. Garrus, J.E.; von Schwedler, U.K.; Pornillos, O.W.; Morham, S.G.; Zavitz, K.H.; Wang, H.E.; Wettstein, D.A.; Stray, K.M.; Côté, M.; Rich, R.L.; et al. Tsg101 and the Vacuolar Protein Sorting Pathway Are Essential for HIV-1 Budding. Cell 2001, 107, 55-65. [CrossRef]

139. Staub, O.; Dho, S.; Henry, P.; Correa, J.; Ishikawa, T.; McGlade, J.; Rotin, D. WW domains of Nedd4 bind to the proline-rich PY motifs in the epithelial $\mathrm{Na}+$ channel deleted in Liddle's syndrome. EMBO J. 1996, 15, 2371-2380. [CrossRef] [PubMed]

140. Babst, M.; Katzmann, D.J.; Estepa-Sabal, E.J.; Meerloo, T.; Emr, S.D. Escrt-III. Dev. Cell 2002, 3, 271-282. [CrossRef]

141. Dunn, R.; Klos, D.A.; Adler, A.S.; Hicke, L. The C2 domain of the Rsp5 ubiquitin ligase binds membrane phosphoinositides and directs ubiquitination of endosomal cargo. J. Cell Biol. 2004, 165, 135-144. [CrossRef] [PubMed]

142. Spidel, J.L.; Craven, R.C.; Wilson, C.B.; Patnaik, A.; Wang, H.; Mansky, L.M.; Wills, J.W. Lysines Close to the Rous Sarcoma Virus Late Domain Critical for Budding. J. Virol. 2004, 78, 10606-10616. [CrossRef] [PubMed]

143. Ott, D.E.; Coren, L.V.; Sowder, R.C.; Adams, J.; Nagashima, K.; Schubert, U. Equine Infectious Anemia Virus and the UbiquitinProteasome System. J. Virol. 2002, 76, 3038-3044. [CrossRef] [PubMed]

144. Chen, C.; Li, F.; Montelaro, R.C. Functional Roles of Equine Infectious Anemia Virus Gag p9 in Viral Budding and Infection. J. Virol. 2001, 75, 9762-9770. [CrossRef]

145. Heidecker, G.; Lloyd, P.A.; Fox, K.; Nagashima, K.; Derse, D. Late Assembly Motifs of Human T-Cell Leukemia Virus Type 1 and Their Relative Roles in Particle Release. J. Virol. 2004, 78, 6636-6648. [CrossRef]

146. Heidecker, G.; Lloyd, P.A.; Soheilian, F.; Nagashima, K.; Derse, D. The Role of WWP1-Gag Interaction and Gag Ubiquitination in Assembly and Release of Human T-Cell Leukemia Virus Type 1. J. Virol. 2007, 81, 9769-9777. [CrossRef] [PubMed]

147. Medina, G.; Pincetic, A.; Ehrlich, L.S.; Zhang, Y.; Tang, Y.; Leis, J.; Carter, C.A. Tsg101 can replace Nedd4 function in ASV Gag release but not membrane targeting. Virology 2008, 377, 30-38. [CrossRef] [PubMed]

148. Bartusch, C.; Prange, R. ESCRT Requirements for Murine Leukemia Virus Release. Viruses 2016, 8, 103. [CrossRef] [PubMed]

149. Vana, M.L.; Tang, Y.; Chen, A.; Medina, G.; Carter, C.; Leis, J. Role of Nedd4 and Ubiquitination of Rous Sarcoma Virus Gag in Budding of Virus-Like Particles from Cells. J. Virol. 2004, 78, 13943-13953. [CrossRef]

150. Stanke, N.; Stange, A.; Lüftenegger, D.; Zentgraf, H.; Lindemann, D. Ubiquitination of the Prototype Foamy Virus Envelope Glycoprotein Leader Peptide Regulates Subviral Particle Release. J. Virol. 2005, 79, 15074-15083. [CrossRef]

151. Yang, Y.; He, Y.; Wang, X.; Liang, Z.; He, G.; Zhang, P.; Zhu, H.; Xu, N.; Liang, S. Protein SUMOylation modification and its associations with disease. Open Biol. 2017, 7, 170167. [CrossRef]

152. Han, Z.-J.; Feng, Y.-H.; Gu, B.-H.; Li, Y.-M.; Chen, H. The post-translational modification, SUMOylation, and cancer (Review). Int. J. Oncol. 2018, 52, 1081-1094. [CrossRef]

153. Matunis, M.J.; Coutavas, E.; Blobel, G. A novel ubiquitin-like modification modulates the partitioning of the Ran-GTPaseactivating protein RanGAP1 between the cytosol and the nuclear pore complex. J. Cell Biol. 1996, 135, 1457-1470. [CrossRef] [PubMed]

154. Owerbach, D.; McKay, E.M.; Yeh, E.T.; Gabbay, K.H.; Bohren, K.M. A proline-90 residue unique to SUMO-4 prevents maturation and sumoylation. Biochem. Biophys. Res. Commun. 2005, 337, 517-520. [CrossRef] [PubMed]

155. Mahajan, R.; Gerace, L.; Melchior, F. Molecular Characterization of the SUMO-1 Modification of RanGAP1 and Its Role in Nuclear Envelope Association. J. Cell Biol. 1998, 140, 259-270. [CrossRef]

156. Saitoh, H.; Hinchey, J. Functional Heterogeneity of Small Ubiquitin-related Protein Modifiers SUMO-1 versus SUMO-2/3. J. Biol. Chem. 2000, 275, 6252-6258. [CrossRef]

157. Desterro, J.M.; Rodriguez, M.S.; Hay, R.T. SUMO-1 Modification of IkB $\alpha$ Inhibits NF-kB Activation. Mol. Cell 1998, 2, 233-239. [CrossRef]

158. Nayak, A.; Müller, S. SUMO-specific proteases/isopeptidases: SENPs and beyond. Genome Biol. 2014, 15, 422. [CrossRef] [PubMed]

159. Tatham, M.H.; Kim, S.; Jaffray, E.; Song, J.; Chen, Y.; Hay, R.T. Unique binding interactions among Ubc9, SUMO and RanBP2 reveal a mechanism for SUMO paralog selection. Nat. Struct. Mol. Biol. 2004, 12, 67-74. [CrossRef] 
160. Eisenhardt, N.; Ilic, D.; Nagamalleswari, E.; Pichler, A. Biochemical characterization of SUMO-conjugating enzymes by in vitro sumoylation assays. Methods Enzym. 2019, 618, 167-185. [CrossRef]

161. Jeon, Y.J.; Yoo, H.M.; Chung, C.H. ISG15 and immune diseases. Biochim. Biophys. Acta (BBA) Mol. Basis Dis. 2010, 1802, 485-496. [CrossRef]

162. Gurer, C.; Berthoux, L.; Luban, J. Covalent Modification of Human Immunodeficiency Virus Type 1 p6 by SUMO-1. J. Virol. 2005, 79, 910-917. [CrossRef]

163. Jaber, T.; Bohl, C.R.; Lewis, G.L.; Wood, C.; West, J.T.; Weldon, R.A. Human Ubc9 Contributes to Production of Fully Infectious Human Immunodeficiency Virus Type 1 Virions. J. Virol. 2009, 83, 10448-10459. [CrossRef]

164. Martinez, N.W.; Xue, X.; Berro, R.G.; Kreitzer, G.; Resh, M.D. Kinesin KIF4 Regulates Intracellular Trafficking and Stability of the Human Immunodeficiency Virus Type 1 Gag Polyprotein. J. Virol. 2008, 82, 9937-9950. [CrossRef] [PubMed]

165. Lamoliatte, F.; McManus, F.P.; Maarifi, G.; Chelbi-Alix, M.K.; Thibault, P. Uncovering the SUMOylation and ubiquitylation crosstalk in human cells using sequential peptide immunopurification. Nat. Commun. 2017, 8, 14109. [CrossRef] [PubMed]

166. Kim, W.; Tang, Y.; Okada, Y.; Torrey, T.A.; Chattopadhyay, S.K.; Pfleiderer, M.; Falkner, F.G.; Dorner, F.; Choi, W.; Hirokawa, N.; et al. Binding of Murine Leukemia Virus Gag Polyproteins to KIF4, a Microtubule-Based Motor Protein. J. Virol. 1998, 72, 6898-6901. [CrossRef]

167. Weldon, A.R.; Sarkar, P.; Brown, S.M.; Weldon, S.K. Mason-Pfizer monkey virus Gag proteins interact with the human sumo conjugating enzyme, hUbc9. Virology 2003, 314, 62-73. [CrossRef]

168. Yueh, A.; Leung, J.; Bhattacharyya, S.; Perrone, L.A.; Santos, K.D.L.; Pu, S.-Y.; Goff, S.P. Interaction of Moloney Murine Leukemia Virus Capsid with Ubc9 and PIASy Mediates SUMO-1 Addition Required Early in Infection. J. Virol. 2006, 80, 342-352. [CrossRef] [PubMed]

169. Wang, J.; Wen, S.; Zhao, R.; Qi, J.; Liu, Z.; Li, W.; An, J.; Wood, C.; Wang, Y. Covalent conjugation of the equine infectious anemia virus Gag with SUMO. Biochem. Biophys. Res. Commun. 2017, 486, 712-719. [CrossRef]

170. Perng, Y.-C.; Lenschow, D.J. ISG15 in antiviral immunity and beyond. Nat. Rev. Genet. 2018, 16, 423-439. [CrossRef] [PubMed]

171. Potter, J.L.; Narasimhan, J.; Mende-Mueller, L.; Haas, A.L. Precursor Processing of Pro-ISG15/UCRP, an Interferon- $\beta$-induced Ubiquitin-like Protein. J. Biol. Chem. 1999, 274, 25061-25068. [CrossRef] [PubMed]

172. Villarroya-Beltri, C.; Guerra, S.; Sánchez-Madrid, F. ISGylation-A key to lock the cell gates for preventing the spread of threats. J. Cell Sci. 2017, 130, 2961-2969. [CrossRef] [PubMed]

173. Zhao, C.; Collins, M.N.; Hsiang, T.-Y.; Krug, R.M. Interferon-induced ISG15 pathway: An ongoing virus-host battle. Trends Microbiol. 2013, 21, 181-186. [CrossRef]

174. Hou, S.X.; Zheng, Z.; Chen, X.; Perrimon, N. The JAK/STAT Pathway in Model Organisms. Dev. Cell 2002, 3, 765-778. [CrossRef]

175. Malakhov, M.P.; Malakhova, O.A.; Kim, K.I.; Ritchie, K.J.; Zhang, D.-E. UBP43 (USP18) Specifically Removes ISG15 from Conjugated Proteins. J. Biol. Chem. 2002, 277, 9976-9981. [CrossRef] [PubMed]

176. Levy, A.J.; Scott, I.; Mackewicz, C. Protection from HIV/AIDS: The importance of innate immunity. Clin. Immunol. 2003, 108, 167-174. [CrossRef]

177. Shirazi, Y.; Pitha, P.M. Alpha interferon inhibits early stages of the human immunodeficiency virus type 1 replication cycle. J. Virol. 1992, 66, 1321-1328. [CrossRef]

178. Cheney, K.M.; Áine, M. Interferon-Alpha Mediates Restriction of Human Immunodeficiency Virus Type-1 Replication in Primary Human Macrophages at an Early Stage of Replication. PLoS ONE 2010, 5, e13521. [CrossRef] [PubMed]

179. Pincetic, A.; Kuang, Z.; Seo, E.J.; Leis, J. The Interferon-Induced Gene ISG15 Blocks Retrovirus Release from Cells Late in the Budding Process. J. Virol. 2010, 84, 4725-4736. [CrossRef]

180. Woods, M.W.; Kelly, J.N.; Hattlmann, C.J.; Tong, J.G.K.; Xu, L.S.; Coleman, M.D.; Quest, G.R.; Smiley, J.R.; Barr, S.D. Human HERC5 restricts an early stage of HIV-1 assembly by a mechanism correlating with the ISGylation of Gag. Retrovirology 2011, 8, 95. [CrossRef]

181. Okumura, A.; Lu, G.; Pitha-Rowe, I.; Pitha, P.M. Innate antiviral response targets HIV-1 release by the induction of ubiquitin-like protein ISG15. Proc. Natl. Acad. Sci. USA 2006, 103, 1440-1445. [CrossRef] [PubMed]

182. Morales, D.J.; Lenschow, D.J. The antiviral activities of ISG15. J. Mol. Biol. 2013, 425, 4995-5008. [CrossRef]

183. Zou, W.; Papov, V.; Malakhova, O.; Kim, K.I.; Dao, C.; Li, J.; Zhang, D.-E. ISG15 modification of ubiquitin E2 Ubc13 disrupts its ability to form thioester bond with ubiquitin. Biochem. Biophys. Res. Commun. 2005, 336, 61-68. [CrossRef]

184. Ambler, R.P.; Rees, M.W. $\epsilon$-N-Methyl-lysine in Bacterial Flagellar Protein. Nat. Cell Biol. 1959, 184, 56-57. [CrossRef]

185. Levy, D. Lysine methylation signaling of non-histone proteins in the nucleus. Cell. Mol. Life Sci. 2019, 76, 2873-2883. [CrossRef]

186. Lanouette, S.; Mongeon, V.; Figeys, D.; Couture, J. The functional diversity of protein lysine methylation. Mol. Syst. Biol. 2014, 10, 724. [CrossRef]

187. Blanchet, F.; Cardona, A.; Letimier, F.A.; Hershfield, M.S.; Acuto, O. CD28 costimulatory signal induces protein arginine methylation in T cells. J. Exp. Med. 2005, 202, 371-377. [CrossRef] [PubMed]

188. Smith, W.A.; Schurter, B.T.; Wong-Staal, F.; David, M. Arginine Methylation of RNA Helicase A Determines Its Subcellular Localization. J. Biol. Chem. 2004, 279, 22795-22798. [CrossRef] [PubMed]

189. Willemsen, N.M.; Hitchen, E.M.; Bodetti, T.J.; Apolloni, A.; Warrilow, D.; Piller, S.C.; Harrich, D. Protein methylation is required to maintain optimal HIV-1 infectivity. Retrovirology 2006, 3, 92. [CrossRef] 
190. Lochmann, T.L.; Bann, D.V.; Ryan, E.P.; Beyer, A.R.; Mao, A.; Cochrane, A.; Parent, L.J. NC-mediated nucleolar localization of retroviral gag proteins. Virus Res. 2013, 171, 304-318. [CrossRef] [PubMed]

191. Invernizzi, C.D.F.; Xie, B.; Frankel, F.A.; Feldhammer, M.; Roy, B.B.; Richard, S.; Wainberg, M.A. Arginine methylation of the HIV-1 nucleocapsid protein results in its diminished function. AIDS 2007, 21, 795-805. [CrossRef] [PubMed]

192. Paris, J.; Tobaly-Tapiero, J.; Giron, M.-L.; Burlaud-Gaillard, J.; Buseyne, F.; Roingeard, P.; Lesage, P.; Zamborlini, A.; Saib, A. The invariant arginine within the chromatin-binding motif regulates both nucleolar localization and chromatin binding of Foamy virus Gag. Retrovirology 2018, 15, 48. [CrossRef] [PubMed] 